\title{
Sulfur isotope values in the sulfidic Frasassi cave system, central Italy: A case study of a chemolithotrophic S-based ecosystem
}

\author{
Aubrey L. Zerkle ${ }^{*}$, Daniel S. Jones ${ }^{2}$, James Farquhar ${ }^{3}$, and Jennifer L. Macalady ${ }^{4}$ \\ ${ }^{1}$ Department of Earth \&Environmental Sciences, University of St Andrews, St Andrews, Fife, \\ KY16 9AL, Scotland, UK \\ ${ }^{2}$ Department of Earth Sciences, University of Minnesota, Minneapolis, MN, 55455, USA \\ ${ }^{3}$ Department of Geology and Earth Systems Science Interdisciplinary Center, University of \\ Maryland, College Park, MD, 20742, USA \\ ${ }^{4}$ Department of Geosciences, Pennsylvania State University, University Park, PA, 16802, \\ USA
}

\footnotetext{
Re-submitted to Geochimica et Cosmochimica Acta

*corresponding author az29@st-andrews.ac.uk
} 


\begin{abstract}
Sulfide oxidation forms a critical step in the global sulfur cycle, although this process is notoriously difficult to constrain due to the multiple pathways and highly reactive intermediates involved. Multiple sulfur isotopes $\left(\delta^{34} S\right.$ and $\left.\Delta^{33} S\right)$ can provide a powerful tool for unravelling sulfur cycling processes in modern (and ancient) environments, although they have had limited application to systems with well-resolved oxidative S cycling. In this study, we report the major $\left(\delta^{34} S\right)$ and minor $\left(\Delta^{33} S\right)$ isotope values of sulfur compounds in streams and sediments from the sulfidic Frasassi cave system, Marche Region, Italy. These microaerophilic cave streams host prominent white biofilms dominated by chemolithotrophic organisms that oxidize sulfide to $S^{0}$, allowing us to estimate $S$ isotope fractionations associated with in situ sulfide oxidation and to evaluate any resulting isotope biosignatures. Our results demonstrate that chemolithotrophic sulfide oxidation produces ${ }^{34} \mathrm{~S}$ enrichments in the $S^{0}$ products that are larger than those previously measured in laboratory experiments, with ${ }^{34} \varepsilon$ S0-H2S of up to $8 \%$ calculated. These small reverse isotope effects are similar to those produced during phototrophic sulfide oxidation $(\leq 7 \%)$, but distinct from the small normal isotope effects previously calculated for abiotic oxidation of sulfide with $\mathrm{O}_{2}(\sim-5 \%)$. An inverse correlation between the magnitude of ${ }^{34} \varepsilon_{\mathrm{S} 0-\mathrm{H} 2 \mathrm{~S}}$ effects and sulfide availability, along with substantial differences in $\Delta^{33} \mathrm{~S}$, both support complex sulfide oxidation pathways and intracellular recycling of S intermediates by organisms inhabiting the biofilms. At the ecosystem level, we calculate fractionations of less than $40 \%$ between sulfide and sulfate in the water column and in the sediments. These fractionations are smaller than those typically calculated for systems dominated by sulfate reduction $(>50 \%)$, and contrast with the commonly held assumption that oxidative recycling of sulfide generally increases overall fractionations. The relatively small fractionations appear to be related to the sequestration of $S^{0}$ in the biofilms (either intra- or extra-cellularly), which removes this intermediate substrate
\end{abstract}


from fractionation by further disproportionation or oxidation reactions. In addition, the net ${ }^{33} \lambda_{\mathrm{H} 2 \mathrm{~S}-\mathrm{SO}} 4$ values calculated in this system are larger than data published for systems dominated by reductive sulfur cycling, partially due to the isotopic imprint of chemolithotrophic sulfide oxidation on the aqueous sulfide pool. These distinct isotopic relationships are retained in the sedimentary sulfur pool, suggesting that trends in ${ }^{34} \mathrm{~S}$ and ${ }^{33} \mathrm{~S}$ isotope values could provide an isotopic fingerprint of such chemolithotrophic ecosystems in modern and ancient environments.

\section{INTRODUCTION}

Sulfur (S) plays an important role in global biogeochemical cycling on Earth. It is nearly ubiquitous in natural systems, where it can exist in multiple redox states $\left(S^{2-}\right.$ to $\left.S^{6+}\right)$ and participate in numerous geochemical and biochemical processes. Sulfate $\left(\mathrm{SO}_{4}{ }^{2-}\right)$ is the most abundant soluble form of sulfur in modern aqueous systems, primarily sourced via fluvial runoff from land. This sulfate provides an important substrate for anaerobic respiration in marine sediments, with dissimilatory sulfate reduction (DSR) accounting for up to $50 \%$ of total carbon remineralization in marine sediments (Jorgensen, 1982). Hydrogen sulfide $\left(\mathrm{H}_{2} \mathrm{~S}\right)$ is a product of DSR, and can accumulate to appreciable $(\mathrm{mM})$ concentrations in anoxic waters and sediments. In modern marine settings, the majority of $\mathrm{H}_{2} \mathrm{~S}$ is recycled within the sediment, and oxidized back to sulfate. The remainder $\sim 10-20 \%$ is buried as pyrite and other iron sulfides (Canfield and Teske, 1996; Jorgensen, 1990).

Oxidative recycling of sulfide is governed by a complex series of heterogeneous biological and abiotic pathways. Sulfide oxidizes abiotically by reaction with Fe(III), $\mathrm{Mn}(\mathrm{IV})$, or by rapid reaction with molecular oxygen. Sulfide oxidation is also an important energy-yielding metabolism in a range of prokaryotic organisms that are diverse and widespread in natural ecosystems. These organisms include photoautotrophs that use reduced 
sulfur compounds as electron donors for anoxygenic photosynthesis, and chemolithotrophs that can oxidize reduced sulfur aerobically with $\mathrm{O}_{2}$ or anaerobically with $\mathrm{NO}_{3}{ }^{-}$. Notably, chemolithotrophic S-oxidizing organisms play an important role in anoxic marine sediments where chemical oxidants are either absent or present at very low concentrations (e.g., Bruchert et al., 2003; Pellerin et al., 2015). In addition to sulfide oxidation, these organisms can perform a wide array of oxidation reactions that involve highly reactive intermediate sulfur compounds, including thiosulfate $\left(\mathrm{S}_{2} \mathrm{O}_{3}{ }^{2-}\right)$, sulfite $\left(\mathrm{SO}_{3}{ }^{2-}\right)$, and elemental sulfur $\left(\mathrm{S}^{0}\right)$. Thiosulfate has been implicated as an important product of sulfide oxidation, although it is quickly recycled in anoxic marine sediments (Jorgensen, 1990). Of the intermediate compounds, only $S^{0}$ builds up to appreciable concentrations in most natural environments (Troelsen and Jorgensen, 1982).

Studies of the stable isotope ratios of sulfur compounds $\left({ }^{32} \mathrm{~S}\right.$ and $\left.{ }^{34} \mathrm{~S}\right)$ have long played an important role in constraining complex biogeochemical sulfur cycling in modern environments (e.g., Habicht and Canfield, 2001; Kaplan et al., 1963). By proxy, the distribution of sulfur isotopes preserved in geologic materials, as pyrite and sulfate evaporites or carbonate associated sulfate, can reveal information about how the sulfur cycle was operating on the early Earth. The record of $\delta^{34} \mathrm{~S}$ preserved in ancient marine sediments has been used to constrain the early history of Earth surface oxidation and to infer the evolution of various sulfur metabolisms on Earth (Canfield and Teske, 1996; Schidlowski et al., 1983). More recently, the inclusion of minor sulfur isotopes, notably ${ }^{33} \mathrm{~S}$, in such studies has proven a valuable tool in unravelling complex biogeochemical sulfur cycling in both modern and ancient systems (Canfield et al., 2010; Johnston et al., 2005b; Kamyshny et al., 2011; Li et al., 2010; Zerkle et al., 2010).

Interpretation of sulfur isotope signatures in the environment and in the rock record is based on decades of research into the magnitude and controls on sulfur isotope fractionation 
by pure cultures and mixed populations of sulfur cycling organisms in laboratory experiments. DSR has received the most attention, due to its importance in the marine $\mathrm{S}$ cycle and its dominance of the resulting isotopic signatures (e.g., Canfield, 2001; Habicht and Canfield, 2001; Kaplan and Rittenberg, 1964). DSR generally produces sulfides depleted in ${ }^{34} \mathrm{~S}$ by more than $40 \%$, although the fractionations vary with the organism, the sulfate concentration, temperature, and electron donor availability (Bradley et al., 2015; Bruchert, 2004; Canfield et al., 2006; Detmers et al., 2001; Habicht et al., 2002; Harrison and Thode, 1958; Kaplan and Rittenberg, 1964; Sim et al., 2011b). Biological disproportionation of S intermediates can also produce large isotope effects, with product $\mathrm{H}_{2} \mathrm{~S}$ generally depleted in ${ }^{34} \mathrm{~S}$ by $5-7 \%$, and product $\mathrm{SO}_{4}{ }^{2-}$ generally enriched in ${ }^{34} \mathrm{~S}$ by $17-21 \%$ (Canfield and Thamdrup, 1994).

Studies of sulfur isotope fractionation during oxidation reactions are limited, presumably due to the complexity of the different reaction processes and the high reactivity of the product intermediates. Experimental studies suggest that abiotic oxidation of sulfide with molecular oxygen can enrich the reactant sulfide in ${ }^{34} \mathrm{~S}$ by up to $5 \%$ o (Fry et al., 1986), while phototrophic sulfide oxidation can cause ${ }^{34} \mathrm{~S}$ depletions of up to $\sim 4 \%$ for $\delta^{34} \mathrm{~S}$, with small changes in $\Delta^{33} \mathrm{~S}$ signatures (Zerkle et al., 2009, and references therein). Measurements of $\mathrm{S}$ isotope fractionations produced by chemolithotrophic organisms utilizing oxygen or nitrate to oxidize reduced $\mathrm{S}$ are particularly limited, presumably because many of the environmentally-relevant S-oxidizing organisms are difficult to cultivate, and only a few strains have been successfully isolated. Previous laboratory experiments with S-oxidizers have yielded inconsistent results, with fractionations varying from -6 to $+5 \%$ (for ${ }^{34} \varepsilon$, as defined in section 2.4), depending on the substrate oxidized and the growth stage in batch cultures (Table 1). 
Fractionations in $\delta^{34} \mathrm{~S}$ between sulfide and sulfate in modern environments and in ancient sediments are often greater than what is typically expressed by DSR alone, from 50 to 70\%o (Canfield, 2001; Canfield and Teske, 1996; Fry et al., 1991; Neretin et al., 2003). Large fractionations of up to $70 \%$ have only recently been measured in incubations with natural populations and pure cultures of sulfate reducers (Canfield et al., 2010; Sim et al., 2011a). These large fractionations during DSR could single-handedly explain the $\mathrm{S}$ isotope values in some natural systems (Canfield et al., 2010; Li et al., 2010; Wortmann et al., 2001). In other systems, large fractionations seem to require sulfate reduction followed by the recycling of sulfide by oxidation and disproportionation reactions (Canfield and Teske, 1996; Canfield and Thamdrup, 1994; Habicht et al., 1998; Zerkle et al., 2010). Despite the relatively smaller fractionations inferred for sulfide oxidation processes in comparison, models suggest these processes can have important consequences for the overall isotopic signatures preserved in natural systems, especially for $\Delta^{33} \mathrm{~S}$ (Zerkle et al., 2009). Additionally, recognizing signatures of S oxidation processes in the rock record is important for testing hypotheses concerning the advent of oxidative sulfur cycling and the evolution of Earth surface redox (Bailey et al., 2013; Johnston et al., 2005b; Lepland et al., 2014).

In this study, we investigate the major and minor sulfur isotope values $\left(\delta^{34} S\right.$ and $\left.\Delta^{33} S\right)$ of sulfur compounds associated with streams, biofilms, and sediments in the sulfidic Frasassi cave system of central Italy. Visible white biofilms in the Frasassi cave streams are up to 5 mm thick, and span the sharp redox interface that occurs within fast-moving cave streams or at the sediment-water interface of more stagnant waters (Macalady et al., 2008; Jones et al., 2015). These biofilms are overwhelmingly dominated by sulfide-oxidizing organisms $(\geq 90 \%$ filamentous Gamma- and Epsilonproteobacteria) that harness the chemical energy of sulfide and oxygen from the cave waters to grow chemolithotrophically (Hamilton et al., 2014; Macalady et al., 2008). Furthermore, a wide range of physicochemical conditions (e.g., 
temperature, $\mathrm{H}_{2} \mathrm{~S}$ and $\mathrm{O}_{2}$ concentrations) exist within the cave streams due to complex hydrology and varying degrees of meteoric dilution of the persistently sulfidic aquifer. This system therefore provides an ideal natural laboratory to estimate the $\mathrm{S}$ isotope fractionations associated with in situ sulfide oxidation by chemolithotrophs, and to examine how these fractionations vary across a range of environmental parameters. In addition, this is the first study of multiple sulfur isotope values associated with $\mathrm{S}$ species in a natural sulfidic system characterized by a complete absence of light, and as such will provide valuable insight into sulfur cycling in aphotic ecosystems.

\section{MATERIALS AND METHODS}

\subsection{The Frasassi cave system}

Samples for this study were collected from the sulfide-rich Frasassi cave system (43.3983 N, 12.9621 E) in the Marche Region, Italy. The caves are actively forming in Jurassic limestones (Calcare Massiccio and Maiolica Formations) in the Frasassi Gorge (Galdenzi and Maruoka, 2003; Mariani et al., 2007). In the caves, sulfidic springs form fast flowing microaerophilic streams and stagnant lakes that can be accessed by technical caving routes (Figure 1a). The sulfidic cave waters are circumneutral ( $\mathrm{pH}$ 7-7.5) and slightly saline (conductivity 1-3.5 mS/cm), with low oxygen $(<25 \mu \mathrm{M})$ and sulfide concentrations up to 600 $\mu \mathrm{M}$. General characteristics of the hydrogeology and geochemistry of the Frasassi karst system are described in detail elsewhere (Jones et al., 2015; Galdenzi et al., 2008; Galdenzi and Maruoka, 2003; Macalady et al., 2006).

\subsection{Sampling}

Cave streams and outflows were sampled at seven separate sites (Figure 2) over three field seasons, in September of 2009, April of 2010, and August of 2011. These included four sites within the cave system: Pozzo dei Cristali (PC), Ramo Sulfurea (RS), Grotta Sulfurea 
(GS), and Lago Verde (LV); and three sites where springs emerged outside of the main cave system into Frasassi Gorge: Cave Spring (CS), Fissure Spring (FS), and Vecchio (VC).

Within the cave system, sites PC, RS, and GS are fast-flowing and turbulent sulfidic streams, while site LV is a stagnant sulfidic lake (Table 2). Temperature, $\mathrm{pH}$, and specific conductivity were measured with standard probes in situ. Oxygen and sulfide concentrations were also measured in situ, by indigo carmine (Hach method 8316) and methylene blue (Hach method 690) methods using a portable spectrophotometer. Duplicate analyses of sulfide were within $1 \%$ of each other; duplicate analyses of oxygen were within $5 \%$ of each other. In 2011, sulfide was also measured from water samples fixed with $2 \% \mathrm{Zn}$-acetate by the methylene blue assay with a laboratory UV spectrophotometer (Cline, 1969). Sulfate concentrations were measured by barium sulphate precipitation (Hach method 8051).

Water samples for dissolved sulfate and sulfide $\mathrm{S}$ isotopes were collected adjacent to the biofilms by syringe and fixed immediately to $2 \% \mathrm{Zn}$-acetate. The product $\mathrm{ZnS}$ was first collected onto $0.2 \mu \mathrm{m}$ GF filters and frozen. An appropriate concentration of $\mathrm{BaCl}_{2}$ was added to the supernatant to precipitate $\mathrm{BaSO}_{4}$, which was similarly filtered and stored frozen. Streamer biofilms were carefully sampled from flowing cave streams using tweezers or pipets. White biofilms from the sediment surface were similarly collected with pipets using care to avoid underlying sediment. Clean sediments with no visible biofilms were collected with a small scoop or pipet. All biofilm and sediment samples were immediately fixed to $2 \%$ $\mathrm{Zn}$-acetate and frozen for storage.

\subsection{Sample preparation and isotope analyses}

Sulfur isotope samples were converted to $\mathrm{Ag}_{2} \mathrm{~S}$ for isotopic analyses via wellestablished protocols (e.g., Zerkle et al., 2010). Briefly, samples for dissolved sulfide (as $\mathrm{ZnS}$ ) and sediment acid-volatile sulfur (AVS) were redistilled to $\mathrm{H}_{2} \mathrm{~S}$ gas by boiling with $5 \mathrm{M}$ $\mathrm{HCl}$ in an enclosed distillation apparatus flushed with $\mathrm{N}_{2}$ gas, and captured as $\mathrm{Ag}_{2} \mathrm{~S}$ with an 
$\mathrm{AgNO}_{3}$ trapping solution. The sediments were subsequently distilled with a $\mathrm{Cr}(\mathrm{II})$ reduction solution (CRS) to reduce elemental sulfur and pyrite to $\mathrm{H}_{2} \mathrm{~S}$ gas (Canfield, 1989) and similarly captured in a second $\mathrm{AgNO}_{3}$ trap. Samples for dissolved sulfate (as $\mathrm{BaSO}_{4}$ ) were reduced to $\mathrm{H}_{2} \mathrm{~S}$ gas by boiling in a solution of $320 \mathrm{~mL} / \mathrm{L} \mathrm{HI}, 524 \mathrm{~mL} / \mathrm{L} \mathrm{HCl}$, and $156 \mathrm{~mL} / \mathrm{L}$ $\mathrm{H}_{2} \mathrm{PO}_{4}$ (Forrest and Newman, 1977) and similarly captured as $\mathrm{Ag}_{2} \mathrm{~S}$. Biofilm samples were freeze-dried in the laboratory, and elemental sulfur was extracted from the biofilms three times by $100 \mathrm{~mL}$ of chloroform, and evaporated to $\sim 1 \mathrm{~mL}$ volume. The concentrated extractions were reduced to $\mathrm{H}_{2} \mathrm{~S}$ utilizing a modified CRS solution with ethanol optimized for $\mathrm{S}^{0}$ extraction (following Groger et al., 2009) and captured as $\mathrm{Ag}_{2} \mathrm{~S}$. For all samples, resulting $\mathrm{Ag}_{2} \mathrm{~S}$ was cleaned with multiple rinses of Milli Q water and $1 \mathrm{M} \mathrm{NH} \mathrm{NH}_{4} \mathrm{OH}$ to remove extra $\mathrm{Ag}^{+}$ ions, and dried overnight.

Sulfur isotope values $\left({ }^{32} \mathrm{~S},{ }^{33} \mathrm{~S}\right.$, and $\left.{ }^{34} \mathrm{~S}\right)$ were measured by the sulfur-hexafluoride method in the Stable Isotope Laboratory at the University of Maryland. $\mathrm{Ag}_{2} \mathrm{~S}$ was reacted in Ni bombs with $10 \times$ excess $\mathrm{F}_{2}$ gas at $\sim 250^{\circ} \mathrm{C}$ for $\sim 8 \mathrm{~h}$, to quantitatively convert the $\mathrm{Ag}_{2} \mathrm{~S}$ to $\mathrm{SF}_{6}$. Product $\mathrm{SF}_{6}$ was then purified cryogenically (distilled at $-115^{\circ} \mathrm{C}$ ) and chromatographically on a 120 molecular sieve $5 \AA$ /Hasep Q column with a TCD. The isotopic abundance of the purified $\mathrm{SF}_{6}$ was analyzed on a Finnigan MAT 253 dual inlet mass spectrometer at m/e- values of 127,128 , and $129\left({ }^{32} \mathrm{SF}_{5}{ }^{+},{ }^{33} \mathrm{SF}_{5}{ }^{+}\right.$, and $\left.{ }^{34} \mathrm{SF}_{5}{ }^{+}\right)$. Analytical uncertainties on $\mathrm{S}$ isotope measurements, estimated from long term reproducibility of $\mathrm{Ag}_{2} \mathrm{~S}$ fluorinations at UMD, are 0.14 for $\delta^{34} \mathrm{~S}$ and 0.008 for $\Delta^{33} \mathrm{~S}$ (both $1 \sigma$ ).

\subsection{Isotope notation}

Isotope ratios measured in individual sulfur species are reported in permil (\%o) using the standard delta notation relative to the Vienna Canyon Diablo Troilite (VCDT) reference material:

$$
\delta^{x} S=1000 \times\left({ }^{3 x} R_{\text {sample }} /{ }^{3 x} R_{V C D T}-1\right)
$$


Where ${ }^{3 x} R_{\text {sample }}$ is the isotope ratio of a sample $\left({ }^{3 x} S /{ }^{32} S\right.$ for $3 x=34$ or 33). Minor isotope values (for ${ }^{33} \mathrm{~S}$ ) measured in individual species are reported using the capital delta notation (in $\%$ ):

$$
\Delta^{33} S=\delta^{33} S-1000 \times\left[\left({ }^{34} R_{\text {sample }} /{ }^{34} R_{V C D T}\right)^{0.515}-1\right] .
$$

In the above equation, the exponent 0.515 is a reference value assigned to approximate massdependent fractionations during thermodynamic equilibrium fractionation processes at low temperatures (e.g., Farquhar et al., 2003; Hulston and Thode, 1965). Following this equation, $\Delta^{33} \mathrm{~S}$ values are positive when the sample is enriched in ${ }^{33} \mathrm{~S}$ with respect to typical mass dependent values, and $\Delta^{33} \mathrm{~S}$ values are negative when the sample is depleted in ${ }^{33} \mathrm{~S}$ with respect to typical mass dependent values.

Measured isotope ratios were also used to calculate the fractionations between separate reservoirs of sulfur in the system (e.g., aqueous sulfate and sulfide), following:

$$
{ }^{34} \varepsilon_{B-A}=1000 \times\left(\frac{{ }^{34} R_{B}}{{ }^{34} R_{A}}-1\right)
$$

where A and B represent the two sulfur pools of interest. Using this definition, for any generalized reaction $\mathrm{A} \rightarrow \mathrm{B}$ between two sulfur pools, a positive value for ${ }^{34} \varepsilon_{\mathrm{B}-\mathrm{A}}$ means that the product $\mathrm{S}$ pool is enriched in the minor isotope $\left({ }^{34} \mathrm{~S}\right)$ in comparison to the reactant $\mathrm{S}$ pool (a reverse isotope effect), and a negative value means that the product $\mathrm{S}$ pool is depleted in ${ }^{34} \mathrm{~S}$ in comparison to the reactant $\mathrm{S}$ pool (a normal isotope effect).

To further compare the mass-dependent fractionation in ${ }^{33} \mathrm{~S}$ between two sulfur pools, we calculated $\Delta^{33} \mathrm{~S}_{\mathrm{B}-\mathrm{A}}$ as: 


$$
\Delta^{33} S_{B-A}=1000 \times\left(\frac{{ }^{33} R_{B}}{{ }^{33} R_{A}}-\frac{{ }^{34} R_{B}}{{ }^{34} R_{A}}{ }^{0.515}\right)
$$

and we calculated the slope of the line on a $\delta^{33} \mathrm{~S}$ versus $\delta^{34} \mathrm{~S}$ plot $\left({ }^{33} \lambda_{\mathrm{B}-\mathrm{A}}\right)$ as:

$$
{ }^{33} \lambda_{B-A}=\frac{\ln \left(\frac{33 R_{B}}{{ }^{33} R_{A}}\right)}{\ln \left(\frac{34 R_{B}}{{ }^{34} R_{A}}\right)} .
$$

We stress that the $\lambda$ values we calculate here represent a net slope between sulfur pools in the system rather than process-specific values, since there is likely more than one process relating the various pools of sulfur in the cave system.

\section{RESULTS}

A summary of the general geochemistry and the morphology of the biofilms collected from 2009 to 2011 are shown in Table 2. The temperatures of cave streams was consistently $\sim 14^{\circ} \mathrm{C}$, with the exception of higher temperatures of $17^{\circ} \mathrm{C}$ at Fissure Springs, where the stream directly flows out into Frasassi Gorge and mixes with river water. The $\mathrm{pH}$ and specific conductivity also remained relatively constant, at $\sim 7.3$ and $2-3 \mathrm{mS} / \mathrm{cm}$ respectively. Three of the sampling sites (GS, CS, and VC) generally have slightly lower specific conductivity (1.5$1.6 \mathrm{mS} / \mathrm{cm}$ ), likely due to higher levels of dilution of the sulfidic groundwaters by meteoric input (Galdenzi et al., 2008). Bulk water sulfide and oxygen concentrations were highly variable between sites, with the highest sulfide concentrations (and lowest oxygen concentrations) occurring at sites PC, RS, and FS (Table 2). The molar ratio of $\mathrm{H}_{2} \mathrm{~S} / \mathrm{O}_{2}$ varied over 3 orders of magnitude amongst the sites sampled, from around 1 to greater than 500 . Biofilms were sampled in all but one location (site PC in 2010), because no biofilms were visible at that time. Both rock-attached biofilms in fast-flowing waters (referred to as "streamers" hereafter) and Sediment-Water Interface Biofilms in less turbid waters (referred 
to as "SWIBs" hereafter) were present at most sites (Figure 1b; as described in Jones et al., 2010; Macalady et al., 2008; Macalady et al., 2006).

The sulfur isotope values measured for aqueous sulfate and sulfide, elemental sulfur $\left(S^{0}\right)$ extracted from biofilms, and sedimentary AVS and CRS are listed in Tables 3 and 4 and plotted in Figure 3a. Errors for individual measurements based on replicate analyses were all below the long-term reproducibility of the instrument, namely below 0.14 for $\delta^{34} \mathrm{~S}$ and 0.008 for $\Delta^{33} \mathrm{~S}$ (both $1 \sigma$ ). Sulfide $\delta^{34} \mathrm{~S}$ values ranged from -21 to $-13 \%$, with values showing slight variations between sampling sites. Sulfate $\delta^{34} \mathrm{~S}$ showed a similar range but also some variability within sites, from +16 to $+23 \%$. Both phases carried small but resolvable $\Delta^{33} \mathrm{~S}$ values $(0.012$ to $0.095 \%$ ) typical of those produced during the redistribution of sulfur mass during biogeochemical cycling in natural systems (e.g., Farquhar et al., 2007). Isotope values for $S^{0}$ ranged from -18 to $-10 \%$ for $\delta^{34} S$, with small $\Delta^{33} S$ values $\left(0.026\right.$ to $0.121 \%$ ). The $\delta^{34} S$ values for AVS and CRS ranged from -21 to $-15 \%$ and from -24 to $-15 \%$, respectively. Both sediment extracts again showed small non-zero $\Delta^{33} \mathrm{~S}$ values $(0.044$ to $0.122 \%$ o $)$ consistent with other $\mathrm{S}$ species in the system.

\section{DISCUSSION}

\subsection{Sulfur cycling in Frasassi cave waters and sediments}

The dissolution of evaporites from the underlying Upper Triassic Burano Formation has been implicated as the dominant source of sulfate to the cave waters, with dissolved sulfide in groundwaters being primarily generated by sulfate reduction in organic-rich lenses within these evaporites (Galdenzi et al., 2008; Jones, et al., 2015). The $\delta^{34} \mathrm{~S}$ values of dissolved sulfide and sulfate in cave waters from our study are roughly similar to previous $\delta^{34}$ S measurements (Galdenzi and Maruoka, 2003), supporting a consistent sulfur source to the cave system over yearly- to decadal-timescales. 
Sulfur isotope values for the evaporite input is difficult to directly quantify, as no measurements of $\mathrm{S}$ isotope ratios have been reported for the Burano Fm. The nearest measurements, from the Upper Triassic Kueper Formation in western Europe, range from +13 to $+17 \%$ for $\delta^{34} \mathrm{~S}$ (Alonso-Azcarate et al., 2006; Fanlo and Ayora, 1998; Huerta et al., 2010), and $\Delta^{33} \mathrm{~S}$ values of $\sim 0.02 \%$ have been estimated for the Mesozoic (Wu et al., 2010) (shown as a triangle in Figure $3 b$ ). Assuming similar $\mathrm{S}$ isotope values for the Burano Fm evaporites, the trends in our aqueous sulfate (and sulfide) data can most closely be approximated by this sulfate source being progressively removed via a Rayleigh-type distillation process, e.g., by further DSR in the cave streams and sediments (Figure 3b). This model would suggest that the cave streams are acting as a partially closed system over the spatial and temporal scales we have examined. Ideally this trend would be borne out by sulfate concentration data; however, in the cave system the sulfate concentrations at any one site are primarily reflective of dilution by meteoric waters, which are controlled by complex cave hydrology, rendering a direct correlation between sulfate concentrations and isotope values meaningless. We note that we were unable to reproduce the trends in the data using open-system sulfur cycling models that included sulfate reduction and sulfide oxidation with or without the recycling of S intermediates (e.g., as in Zerkle et al., 2009).

In addition, larger $\Delta^{33} \mathrm{~S}$ values for sulfate $(>0.05 \%)$ in some samples suggest mixing with an additional source of sulfate. This sulfate could be sourced from complete oxidation of sulfide or $S^{0}$ to sulfate, dissolution of gypsum fallen from cave walls (Galdenzi and Maruoka, 2003), or input of dissolved sulfate from meteoric surface waters. The first two sources would propagate the $S$ isotope signatures of aqueous sulfide or $S^{0}$, contributing to larger $\Delta^{33} S$ values; the third is unknown but probably insignificant except in sites external to the cave.

Isotope values of AVS and CRS in Frasassi sediments support additional DSR in the sediments. Porewater sulfide (AVS) was generally depleted in ${ }^{34} \mathrm{~S}$ from dissolved sulfate, 
with calculated ${ }^{34} \varepsilon_{\text {AVS -SO4 }}$ from -41 to $-34 \%$ and net ${ }^{33} \lambda_{\text {AVS-SO4 }}$ of 0.513 to 0.514 (with errors $\leq 0.005$; Table 3 ). These fractionations are generally slightly larger than those directly calculated for the water column (from -39 to $-29 \%$ or for ${ }^{34} \varepsilon_{\mathrm{H} 2 \mathrm{~S}-\mathrm{SO} 4}$ and net ${ }^{33} \lambda_{\mathrm{H} 2 \mathrm{~S}-\mathrm{SO} 4}$ of 0.513 to 0.515 , with errors $\leq 0.006$; Table 3 ), and could reflect additional sulfate reduction fuelled by organic matter from the overlying biofilms. The CRS, which represents a mixture of $\mathrm{S}^{0}$ and pyrite formed in the sediments, was also generally depleted in ${ }^{34} \mathrm{~S}$ from aqueous sulfate, with calculated ${ }^{34} \varepsilon_{\text {CRS-SO4 }}$ from -45 to $-34 \%$ and net ${ }^{33} \lambda_{\text {CRS-SO4 }}$ of 0.513 to 0.515 (with errors $\leq$ 0.002; Table 3). Notably, these fractionations are roughly representative of water column and porewater sulfide (in both $\delta^{34} S$ and $\Delta^{33} S$ ), meaning these values would accurately reflect adjacent $\mathrm{S}$ cycling processes if transferred to the sedimentary record. This possibility is further explored in section 4.3.

\subsection{Sulfur cycling in Frasassi biofilms}

Sulfide from DSR builds up to appreciable levels in Frasassi cave waters, which combines with percolating $\mathrm{O}_{2}$-rich meteoric water from above to provide an ample energy source for extensive chemolithotrophic biofilm communities (Figure 1b). These biofilms are nearly ubiquitous spanning the redox interface and sediments of the cave streams, and can contain up to $50 \mathrm{wt} \%$ sulfur (Hamilton et al., 2014). Multiple lines of both geochemical and biochemical evidence indicate that $\mathrm{S}^{0}$ in the biofilms is a direct product of biological sulfide oxidation. These include: 1) direct measurements of sulfide oxidation rates in cave streams indicating much faster rates for biological sulfide oxidation than for abiotic sulfide oxidation (Jones et al., 2015); 2) pH microsensor profiles through biofilms showing no evidence for significant production of sulfuric acid via complete $\mathrm{H}_{2} \mathrm{~S}$ oxidation (Jones et al., 2015); 3) molecular screening of biofilm communities confirming that sulfide-oxidizing prokaryotes are the dominant micro-organisms (Macalady et al., 2008); and, 4) metagenomic data from the biofilms supporting incomplete oxidation of sulfide to $\mathrm{S}^{0}$ as the dominant sulfide 
oxidation pathway (Hamilton et al., 2014). Once $S^{0}$ is produced, a number of subsequent processes could be acting on it in the biofilms, including reoxidation, reduction, or disproportionation; however, the isotope effects on $\mathrm{S}^{0}$ associated with each of these processes have been shown to be very small to negligible (Canfield and Thamdrup, 1994; Kaplan and Rittenberg, 1962; Nelson and Castenholz, 1981; Schmidt et al., 1987).

Elemental sulfur extracted from the Frasassi cave stream biofilms was typically slightly to moderately enriched in ${ }^{34} \mathrm{~S}$ from aqueous sulfide, with calculated ${ }^{34} \varepsilon_{\mathrm{S} 0-\mathrm{H} 2 \mathrm{~S}}$ values as large as $+8 \%$ (Figure 4 ). Based on the above arguments, these fractionations predominantly reflect a reverse isotope effect produced during chemolithotrophic $\mathrm{H}_{2} \mathrm{~S}$ oxidation. These fractionations are smaller than those calculated for other sulfur cycling processes (Figure 5), but significantly larger than what has been estimated for sulfide oxidation from previous laboratory studies (Table 1). These also differ from the $\sim-5 \%$ normal isotope effect calculated for abiotic reaction of sulfide with $\mathrm{O}_{2}$ (Fry et al., 1988).

Comparable fractionations $\left({ }^{34} \varepsilon \mathrm{s} 0-\mathrm{H} 2 \mathrm{~s}\right.$ up to $+7 \%$ ) have been calculated for phototrophic sulfide oxidation in the laboratory and in natural environments (Figure 5) (Brabec et al., 2012; Zerkle et al., 2009; Zerkle et al., 2010). Similar fractionations could support a similar pathway (or, more specifically, a similar set of intermediate steps) for sulfide oxidation between the two groups of organisms. The biochemical mechanism(s) of chemolithotrophic sulfide oxidation are not well characterized in many of the environmentally relevant organisms, but two enzymatic pathways have generally been proposed. One is the sulfide:quinone oxidoreductase (SQR) pathway, and one is the Sox (sulfur oxidation) pathway (Ghosh and Dam, 2009), both of which have also been described for phototrophs (Frigaard and Bryant, 2008). The SQR pathway forms elemental sulfur (or polysulfides) as a key intermediate during the oxidation of sulfide to sulfate. The Sox system is most well-studied for thiosulfate oxidation, and is also thought to be used for the oxidation 
of other reduced inorganic sulfur compounds, including sulfide (e.g., Sauve et al., 2007). In the complete Sox pathway, sulfide is bound to the multienzyme SoxY-cysteine-sulfur complex and oxidized to sulfite and sulfate without producing intermediate $S^{0}$. However, many organisms, including those found in the cave biofilms, have a partial Sox pathway that lacks SoxCD, and thus produces $S^{0}$ as an intermediate or end product (Hamilton et al., 2014).

We examined these fractionations within the context of bulk water chemistry, specifically concentrations of $\mathrm{H}_{2} \mathrm{~S}$ and $\mathrm{O}_{2}$, to evaluate any environmental controls associated with substrate availability (Figure 4). The sulfide/oxygen supply ratio of bulk cave water has been demonstrated to exert an important control on microbial populations inhabiting stream biofilms, particularly in turbulent waters (Macalady et al., 2008). The fractionations show only a weak correlation with $\mathrm{H}_{2} \mathrm{~S}_{/} \mathrm{O}_{2}\left(\mathrm{R}^{2}=0.3\right)$ for both streamers and SWIBS over the range of concentrations we measured. However, we note that fractionations greater than $+4 \%$ only occur at lower $\mathrm{H}_{2} \mathrm{~S}$ and/or higher $\mathrm{O}_{2}$ concentrations $\left(\mathrm{H}_{2} \mathrm{~S}: \mathrm{O}_{2} \leq 3\right)$, i.e., when the electron donor was limiting. Similar trends have been seen in DSR, with larger isotope effects produced at higher concentrations of sulfate (the electron acceptor) and/or a lower supply rate of electron donors in the form of organic matter, often with a similar threshold value for the limiting nutrient (e.g., Habicht et al., 2002; Sim et al., 2011b). Large isotope effects in multistep microbial metabolisms have been attributed to both bidirectional flow of substrate into and out of the cells, and intracellular recycling of metabolic intermediates, the former in association with slower growth rates during nutrient starvation. For sulfide oxidation, we would not expect a significant bidirectional flow of sulfide into and out of the cells when $\mathrm{H}_{2} \mathrm{~S}$ itself is limiting. We suggest these larger fractionations could be produced by enhanced intracellular recycling of S intermediates, such as via branching within the metabolic pathways to maximize electron flow when the organisms are sulfide-limited. Following this mechanism the largest fractionations should be expressed under conditions of extreme 
substrate starvation, i.e., when cell-specific metabolic rates are at a minimum (Wing and Halevy, 2014).

The biofilms show significant variability in $\Delta^{33} \mathrm{~S}_{\mathrm{S} 0-\mathrm{H} 2 \mathrm{~S}}$, which also implies some additional cycling of sulfur at either the metabolic or the ecosystem level. These signatures support a competition between reactions in a reaction network and/or some level of branching within the sulfide oxidation metabolism(s) (e.g., Farquhar et al., 2007). Branching pathways could occur, for instance, via intracellular recycling of $S^{0}$ within one or more of the above metabolisms and/or the simultaneous shunting of sulfide down multiple pathways for sulfide oxidation within a single cell. Assuming limited backflow of sulfide from within the cell, expression of these isotope effects on the metabolic scale does require some complete oxidation to sulfate or formation of an additional intermediate S compound (e.g., thiosulfate) that we have not quantified here.

The results of the present study emphasize the importance of further characterizing chemolithotrophic sulfide oxidation pathways and associated isotope effects in controlled laboratory experiments with organisms for which the relevant biochemical mechanisms have been identified (e.g., Poser et al., 2014). These types of experiments would allow for a more rigorous examination of the calculated fractionations within the context of numerical models accounting for branching within the specific metabolic pathways. Additionally, examining conditions inductive to a larger range of ${ }^{34} \varepsilon_{\mathrm{S} 0-\mathrm{H} 2 \mathrm{~S}}$ fractionations would allow for a more robust examination of the minor isotope effects, to accurately calculate process-specific ${ }^{33} \lambda_{\mathrm{S} 0-\mathrm{H} 2 \mathrm{~S}}$ for these metabolisms (Johnston et al., 2007). From the data here, it is difficult to resolve these exponents, as the error on ${ }^{33} \lambda$ is heavily dependent on ${ }^{34} \varepsilon$, with very large errors associated with small ${ }^{34} \varepsilon$ values (discussed further below).

\subsection{Comparison with other natural systems}


Previous analyses of minor $\mathrm{S}$ isotope values in aqueous environments have predominantly focused on redox-stratified lakes and marginal marine basins (Figure 6;

Canfield et al., 2010; Johnston et al., 2008; Kamyshny et al., 2011; Li et al., 2010; Zerkle et al., 2010). Sulfur cycling in these systems was generally dominated by sulfate reduction, with sulfide oxidation processes confined to the interface between oxygenated and sulfidic waters. The fractionations between sulfate and sulfide reported in these systems lie within a narrow field in ${ }^{34} \varepsilon_{\mathrm{H} 2 \mathrm{~S}-\mathrm{SO} 4}$ versus ${ }^{33} \lambda_{\mathrm{H} 2 \mathrm{~S}-\mathrm{SO} 4}$ space (shown by the grey box in Figure 6) ranging from 30 and $-65 \%$ and $\sim 0.5110$ to 0.5138 , respectively. In the Frassasi streams we calculate ${ }^{34} \varepsilon_{\mathrm{H} 2 \mathrm{~S} / \mathrm{CRS}-\mathrm{SO} 4}$ values on the low end of the spectrum, and larger net ${ }^{33} \lambda_{\mathrm{H} 2 \mathrm{~S} / \mathrm{CRS}-\mathrm{SO} 4}$ (albeit \pm 0.004; Table 3) in comparison (Figure 6).

Small fractionations in $\delta^{34} \mathrm{~S}$ accompanied by high ${ }^{33} \lambda_{\mathrm{H} 2 \mathrm{~S}-\mathrm{SO}}$ in natural populations of sulfate reducers were interpreted to reflect an increase in the leak of sulfate from the cell back into the environment (Farquhar et al., 2008; based on models of Brunner et al., 2005). This was suggested to occur due to a lower efficiency for uptake of the electron donor compared to the transport of sulfate into and out of the cell. Similarly, small fractionations in $\delta^{34} \mathrm{~S}$ during DSR in the Frasassi system could reflect a paucity of organic matter in comparison to the abundant sulfate in the underlying evaporites where sulfate reduction occurs. Additionally, in many natural environments, fractionations in $\delta^{34}$ S during DSR are enhanced by further oxidation of sulfide and disproportionation of S-intermediates, with additional fractionations accumulating at each step (e.g., Canfield and Teske). In the Frasassi cave streams, oxidation of sulfide produces $\mathrm{S}^{0}$ that is predominantly stored in the biofilms rather than recycled, therefore no significant additional fractionations in $\delta^{34} \mathrm{~S}$ between aqueous sulfide and sulfate are expressed.

The increase in the net ${ }^{33} \lambda_{\mathrm{H} 2 \mathrm{~S} / \mathrm{CRS}-\mathrm{SO} 4}$ signal could be reflecting an isotopic imprint of chemolithotrophic sulfide oxidation on the sulfide pool. Recent models of S isotope effects 
based on porewater sulfate profiles through an anoxic marine sapropel suggested similarly

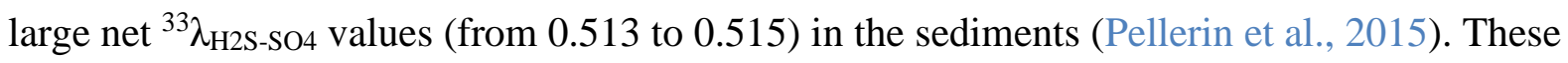
researchers attributed the ${ }^{34} \mathrm{~S}-{ }^{33} \mathrm{~S}$ trends to disproportionation of $\mathrm{S}^{0}$, and suggested that sulfide oxidation would contribute only marginally to these values. Our data suggest otherwise.

It is difficult to resolve a process-specific (or even net) ${ }^{33} \lambda_{\mathrm{S} 0-\mathrm{H} 2 \mathrm{~S}}$ value for chemolithotrophic sulfide oxidation in the Frasassi biofilms, as the error on ${ }^{33} \lambda$ is heavily dependent on ${ }^{34} \varepsilon$. In particular, very large errors for ${ }^{33} \lambda$ are associated with small ${ }^{34} \varepsilon$ values such as those we calculate between $\mathrm{S}^{0}$ and sulfide in the biofilms. If we consider only data spanning the largest range of fractionations measured in the biofilms $\left({ }^{34} \varepsilon_{S} 0-\mathrm{H} 2 \mathrm{~S}>4 \%\right.$ we calculate a net ${ }^{33} \lambda_{\mathrm{S} 0-\mathrm{H} 2 \mathrm{~s}}$ of 0.513 for chemolithotrophic sulfide oxidation, although with very large errors of \pm 0.5 reflective of these small ${ }^{34} \varepsilon$ values (calculated as in Johnston et al., 2007). We stress that this large error precludes calculation of a unique exponent for this process, but point out that this initial estimate for sulfide oxidation would move the sulfide pool towards more positive ${ }^{33} \lambda_{\mathrm{H} 2 \mathrm{~S}-\mathrm{SO} 4}$ values. Regardless of the exact mechanism(s), the difference in the net ${ }^{33} \lambda_{\mathrm{H} 2 \mathrm{~S}-\mathrm{SO} 4}$ between Frasassi and other systems is substantial, suggesting that this signature could be evident even in systems where larger fractionations during DSR occur. This comparison illustrates that large net ${ }^{33} \lambda_{\mathrm{H} 2 \mathrm{~S}-\mathrm{SO} 4}$ values similar to those calculated for the Frasassi cave streams could be useful for recognizing chemolithotrophic sulfide oxidation in modern and ancient ecosystems.

\section{CONCLUSIONS}

The sulfidic Frasassi cave streams and associated biofilms provide an ideal natural laboratory for studying in situ chemolithotrophic sulfur cycling processes and their resulting geochemical signatures. In this study we utilized the multiple sulfur isotope values $\left({ }^{32} \mathrm{~S},{ }^{33} \mathrm{~S}\right.$, and ${ }^{34} \mathrm{~S}$ ) in sulfur compounds within these streams, biofilms, and sediments, to investigate fractionations produced during sulfide oxidation processes, to examine what controls these 
fractionations, and to determine how this process contributes to the isotopic fingerprint of the system. The data we collected offer a number of important new and testable hypotheses into chemolithotrophic sulfur cycling processes both at the cellular scale and at the ecosystem scale.

Within the cave stream biofilms, which are dominated by chemolithotrophic sulfide oxidizers, we measured significant fractionations in $\delta^{34} \mathrm{~S}$ between sulfide and $\mathrm{S}^{0}$. These fractionations vary inversely with the bulk $\mathrm{H}_{2} \mathrm{~S} / \mathrm{O}_{2}$ in stream waters (i.e., the electron donor/acceptor availability), implicating a role for recycling of intermediate sulfur compounds within the chemolithotrophic metabolisms at low $\mathrm{H}_{2} \mathrm{~S}$ availability. This dependence on electron donor availability suggests that even larger fractionations could be produced under conditions of extreme substrate starvation, which could be a common occurrence in natural ecosystems.

At the ecosystem level, sulfate reduction appears to be concentrated in the stream sediments, where it is fuelled by organic carbon input from the overlying biofilms, and drives local drawdown of sulfate within the cave system. Chemolithotrophic sulfide oxidation is the dominant metabolic process in the biofilms, where it sequesters $S^{0}$ from further oxidative recycling, leading to lower overall fractionations in $\delta^{34} S$ than commonly measured in ecosystems dominated by reductive sulfur cycling. This result is contrary to the canonical view that oxidative sulfur cycling should increase overall ${ }^{34} \varepsilon_{\mathrm{H} 2 \mathrm{~S}-\mathrm{SO} 4}$ in sedimentary systems, and its relevance to interpreting $\delta^{34} \mathrm{~S}$ values in ancient sediments requires further study.

Despite the unexpectedly small fractionations in $\delta^{34} \mathrm{~S}$, organic matter limitation of DSR coupled with chemolithotrophic sulfide oxidation in the cave streams appears to promote distinct signatures for ${ }^{33} \mathrm{~S}$ in the water column and sediments that differ from previously studies ecosystems. These minor isotope values could provide a diagnostic signature for environments dominated by chemolithotrophic sulfide oxidation in modern and 
ancient sediments. Such signatures could prove useful in recognizing oxidative sulfur cycling in the early biosphere, for example associated with the progressive oxygenation of the early Earth, or in more recent phosphorite deposits that have been tied to the metabolic activity of chemolithotrophic sulfide oxidizers.

\section{ACKNOWLEDGEMENTS}

The authors thank A. Montanari for providing logistical support and the use of facilities and laboratory space at the Osservatorio Geologico di Coldigioco in Italy. Thanks to S. Mariani, S. Cerioni, M. Mainiero, F. Baldoni, S. Carnevali and members of the Gruppo Speleologico C.A.I. di Fabriano and Ancona for technical assistance during field campaigns, and to S. Dattagupta, R. McCauley, K. Dawson and C. Chan for assistance with sampling. We additionally thank Associated Editor D. Johnston and K. Mandernack for constructive reviews that greatly improved the manuscript. This work was supported by NASA Exobiology (NNX07AV54G) (A.Z. and J.F.), a Natural Environment Research Council Fellowship (NE/H016805) (A.Z.), the National Science Foundation (NSF EAR-0525503 and EAR-1124411) (J.M.), and the NASA Astrobiology Institute (PSARC, NNA04CC06A) (J.M.). 

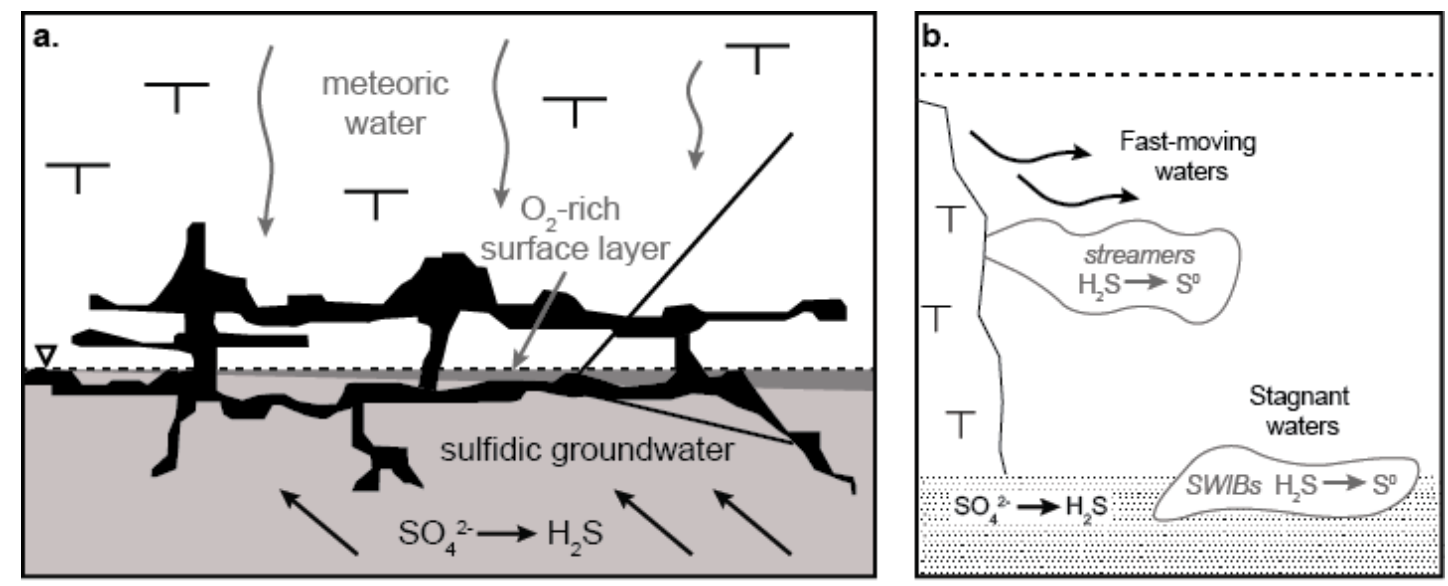

Figure 1. a. Hydrologic setting of the Frasassi cave system forming within the Calcare Massiccio limestone, showing inputs of $\mathrm{O}_{2}$-rich meteoric waters percolating in from above, and sulfide-rich groundwaters rising from below (modified from Galdenzi and Maruoka, 2003). b. Depiction of material sampled for this study. Most samples for this study were collected from microaerophilic streams, in which sulfide oxidation can occur in attached streamers or sediment-water interface biofilms (SWIBs) spanning the redox interface and sulfate reduction predominates in sediments or other oxygen-depleted areas. Schematic based on studies of Macalady et al.(2008), Hamilton et al. (2014), and Jones et al. (2015). 


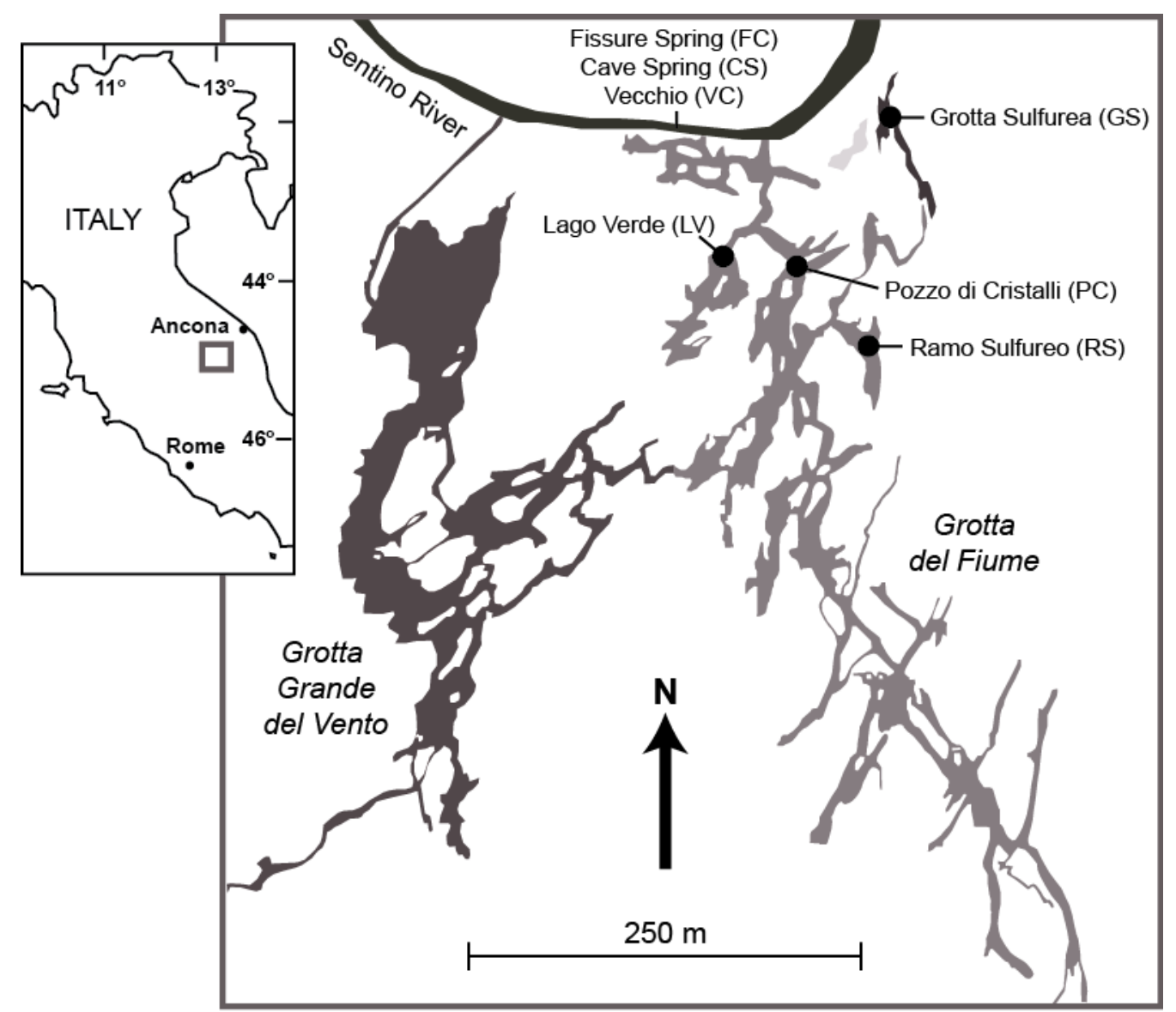

Figure 2. Map of sampling sites in the Frasassi cave system. Base map courtesy of the Gruppo Speleologico CAI di Fabriano. 


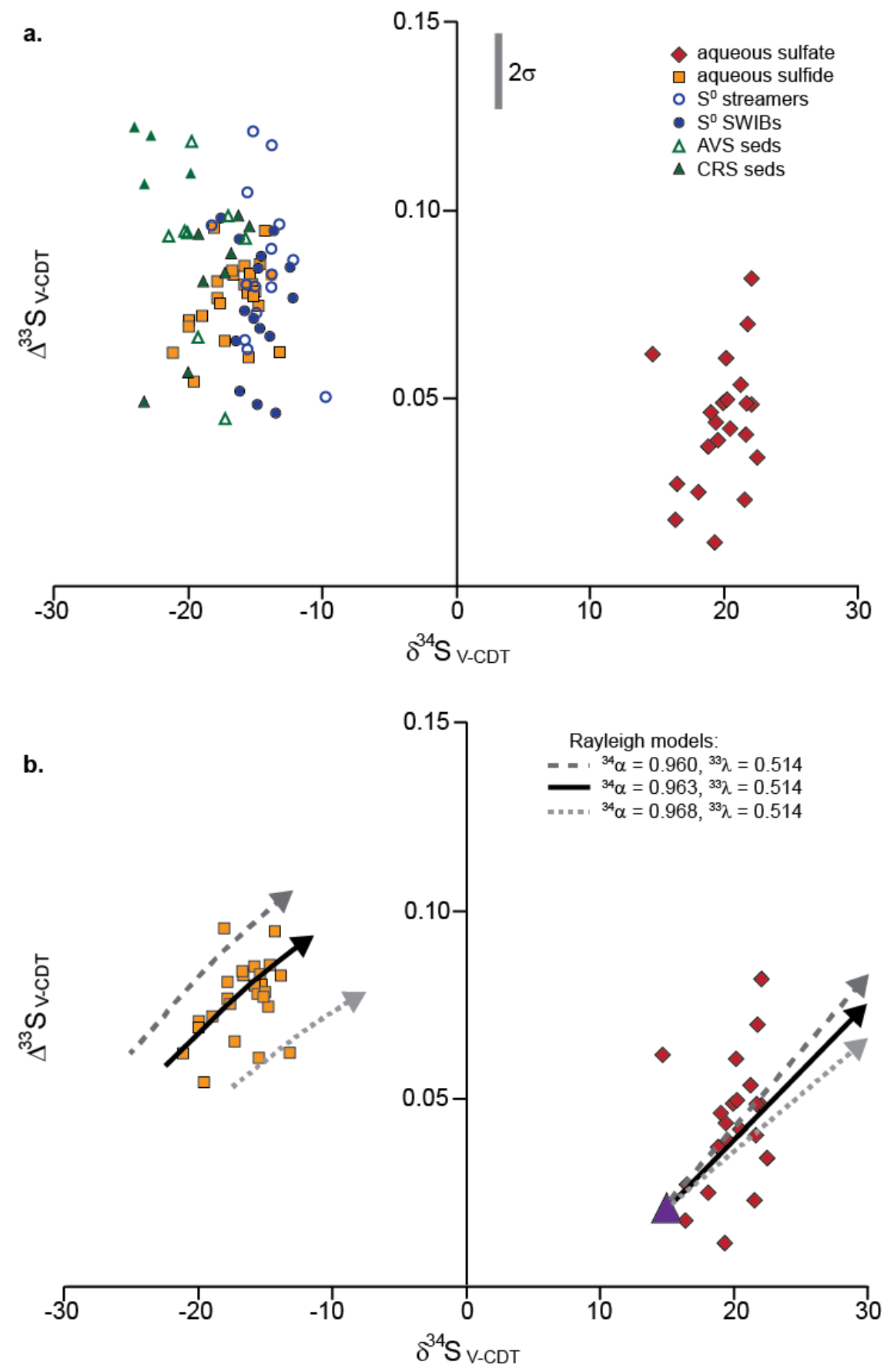

Figure 3. a. Sulfur isotope data for aqueous sulfate and sulfide in cave streams, $S^{0}$ extracted from biofilms, and AVS and CRS extracted from stream sediments. b. Closed system Rayleigh model of isotope effects during DSR, showing a range of values that can approximate the $\mathrm{S}$ isotope trends in aqueous sulfate and sulfide measured in the cave streams. The triangle represents an estimate for source sulfate. 


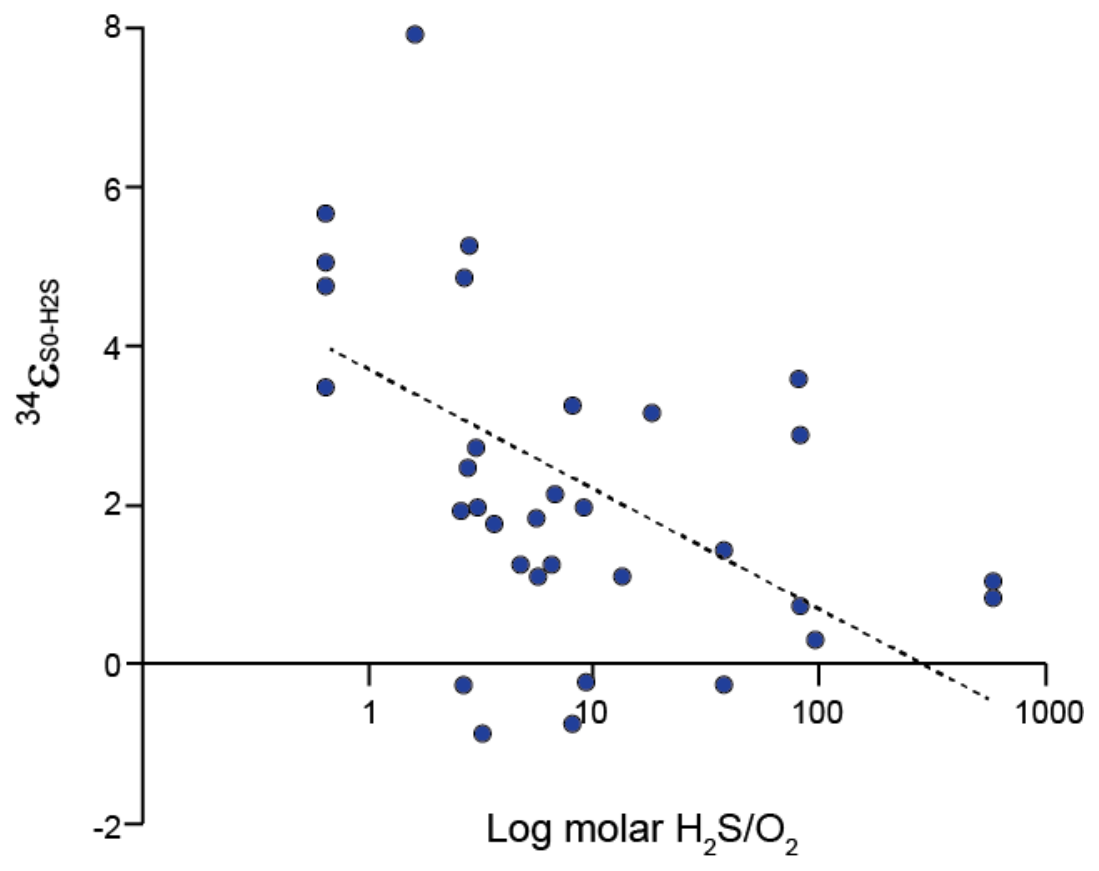

Figure 4. Fractionations between aqueous sulfide and $\mathrm{S}^{0}$ in biofilms plotted versus substrate availability in the bulk waters (log molar electron-donor/electron-acceptor). The dashed line is a best-fit log linear trend, with $\mathrm{R}^{2}=0.3$. 


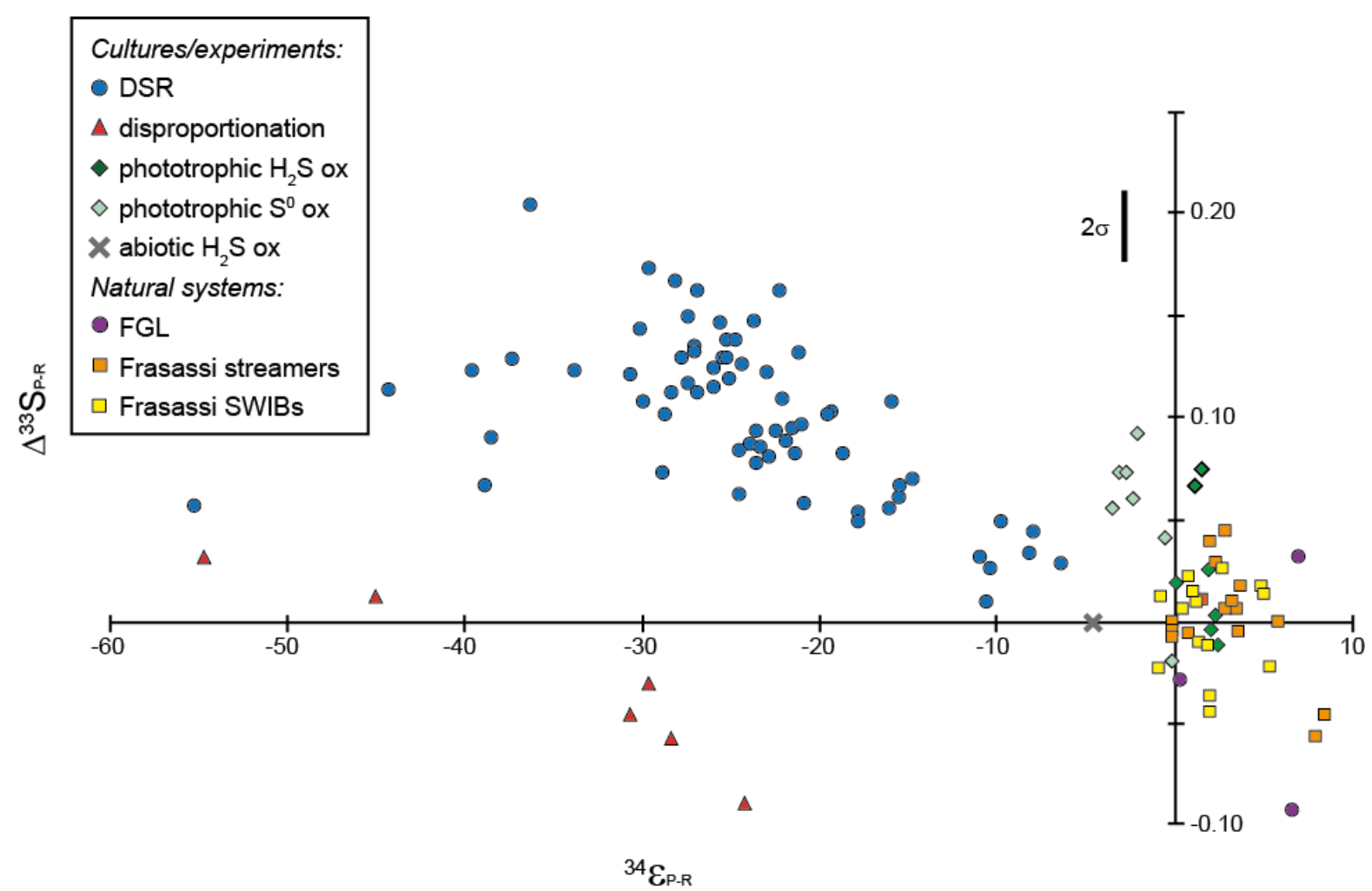

Figure 5. Fractionations in ${ }^{34} \varepsilon$ and $\Delta^{33} \mathrm{~S}$ calculated between product and reactant in Frasassi biofilms compared to those measured for other sulfur cycling metabolisms. These include fractionations measured in cultures of dissimilatory sulfate reducers (data compiled from Johnston et al., 2005a; Sim et al., 2011b), cultures of sulfur compound disproportionaters (from Johnston et al., 2005a), cultures of phototrophic sulfide and $\mathrm{S}^{0}$ oxidizers (from Zerkle et al., 2009), and experiments with abiotic oxidation of sulfide via dissolved $\mathrm{O}_{2}$ (from Fry et al., 1988, shown for ${ }^{34} \varepsilon$ only). Also shown are fractionations between aqueous sulfide and $S^{0}$ in the chemocline of a redox-stratified lake dominated by phototrophic S oxidation (Fayetteville Green Lake, FGL; from Zerkle et al., 2010). 


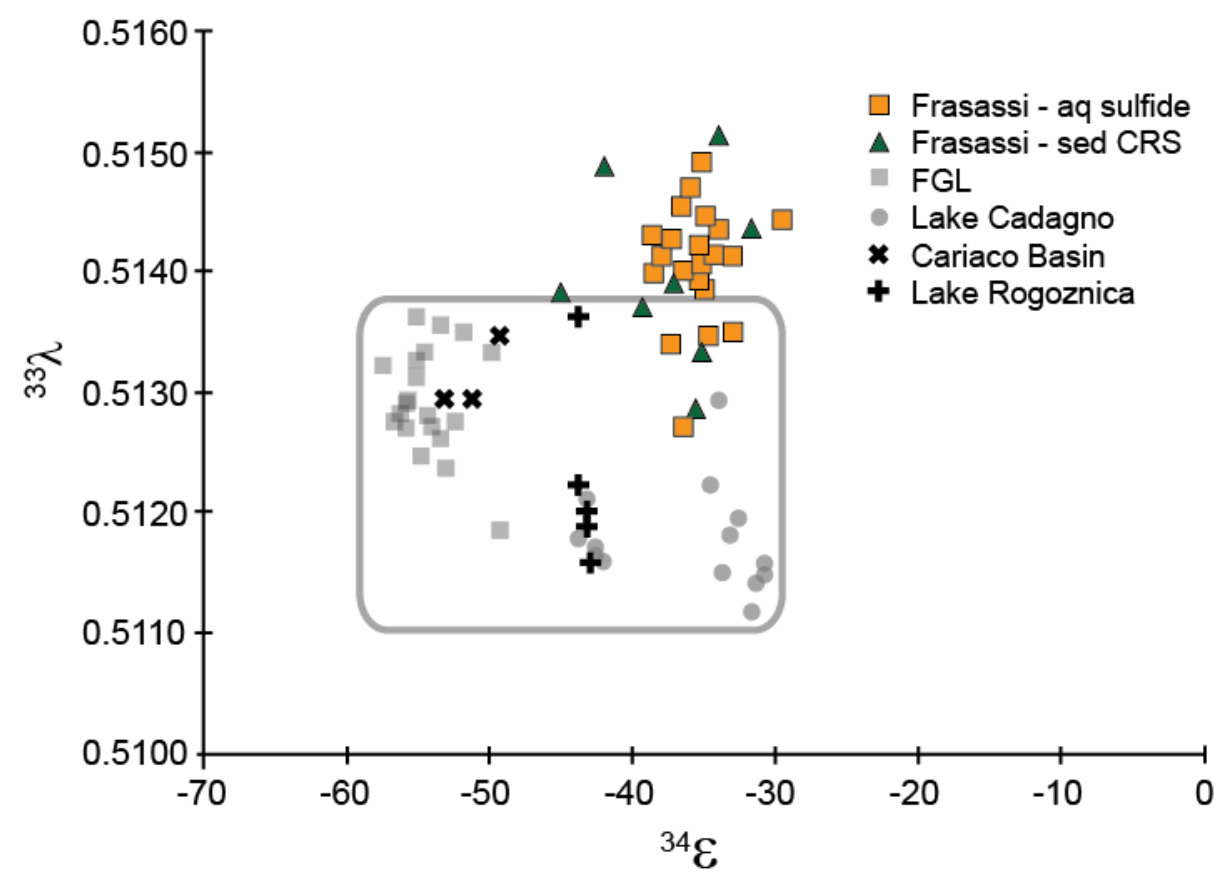

Figure 6. Comparison of fractionations between aqueous sulfate and sulfide in the Frasassi cave streams with previously published data for natural systems (from Canfield et al., 2010; Kamyshny et al., 2011; Li et al., 2010; Zerkle et al., 2010). 


\section{REFERENCES}

Alam, M., Pyne, P., Mazumdar, A., Peketi, A., Ghosh, W., 2013. Kinetic Enrichment of S-34 during Proteobacterial Thiosulfate Oxidation and the Conserved Role of SoxB in S-S Bond Breaking. Applied and Environmental Microbiology 79, 4455-4464.

Alonso-Azcarate, J., Bottrell, S.H., Mas, J.R., 2006. Synsedimentary versus metamorphic control of $\mathrm{S}, \mathrm{O}$ and $\mathrm{Sr}$ isotopic compositions in gypsum evaporites from the Cameros Basin, Spain. Chemical Geology 234, 46-57.

Bailey, J.V., Corsetti, F.A., Greene, S.E., Crosby, C.H., Liu, P., Orphan, V.J., 2013. Filamentous sulfur bacteria preserved in modern and ancient phosphatic sediments: implications for the role of oxygen and bacteria in phosphogenesis. Geobiology 11, 397-405. Balci, N., Mayer, B., Shanks, W.C., III, Mandernack, K.W., 2012. Oxygen and sulfur isotope systematics of sulfate produced during abiotic and bacterial oxidation of sphalerite and elemental sulfur. Geochimica et Cosmochimica Acta 77, 335-351.

Brabec, M., Lyons, T., Mandernack, K., 2012. Oxygen and sulfur isotope fractionation during sulfide oxidation by anoxygenic phototrophic bacteria. Geochimica et Cosmochimica Acta $83,234-251$.

Bradley, A.S., Leavitt, W.D., Schmidt, M., Knoll, A.H., Girguis, P.R. and Johnston, D.T., 2015. Patterns of sulfur isotope fractionation during Microbial Sulfate Reduction. Geobiology doi: 10.1111/gbi.12149.

Bruchert, V., 2004. Physiological and ecological aspects of sulfur isotope fractionation during bacterial sulfate reduction, in: Amend, J.P., Edwards, K.J., Lyons, T.W. (Eds.), Sulfur Biogeochemistry - Past and Present. Geological Society of America, pp. 1-16.

Bruchert, V., Jorgensen, B.B., Neumann, K., Riechmann, D., Schlosser, M., Schulz, H., 2003. Regulation of bacterial sulfate reduction and hydrogen sulfide fluxes in the central Namibian coastal upwelling zone. Geochimica et Cosmochimica Acta 67, 4505-4518. 
Brunner, B., Bernasconi, S.M., Kleikemper, J., Schroth, M.H., 2005. A model for oxygen and sulfur isotope fractionation in sulfate during bacterial sulfate reduction processes.

Geochimica et Cosmochimica Acta 69, 4773-4785.

Canfield, D.E., 1989. Reactive iron in marine sediments. Geochimica et Cosmochimica Acta $53,619-632$.

Canfield, D.E., 2001. Isotope fractionation by natural populations of sulfate-reducing bacteria. Geochimica et Cosmochimica Acta 65, 1117-1124.

Canfield, D.E., Farquhar, J., Zerkle, A.L., 2010. High isotope fractionations during sulfate reduction in a low-sulfate euxinic ocean analog. Geology 38, 415-418.

Canfield, D.E., Oleson, C.A., Cox, R.P., 2006. Temperature and its controle of isotopic fractionation by sulfate-reducing bacterium. Geochimica et Cosmochimica Acta 70, 548-561. Canfield, D.E., Teske, A., 1996. Late Proterozoic rise in atmospheric oxygen concentration inferred from phylogenetic and sulphur-isotope studies. Nature 382, 127-132.

Canfield, D.E., Thamdrup, B., 1994. The production of 34S-depleted sulfide during bacterial disproportionation of elemental sulfur Science 266, 1973-1975.

Cline, J.D., 1969. Spectrophotometric determination of hydrogen sulfide in natural waters. Limnology and Oceanography 14, 454-458.

Detmers, J., Bruchert, V., Habicht, K.S., Kuever, J., 2001. Diversity of sulfur isotope fractionations by sulfate-reducing prokaryotes. Applied and Environmental Microbiology 67, 888-894.

Fanlo, I., Ayora, C., 1998. The evolution of the Lorraine evaporite basin: implications for the chemical and isotope composition of the Triassic ocean. Chemical Geology 146, 135-154. Farquhar, J., Canfield, D.E., Masterson, A., Bao, H., Johnston, D., 2008. Sulfur and oxygen isotope study of sulfate reduction in experiments with natural populations from Faellestrand, Denmark. Geochimica et Cosmochimica Acta 72, 2805-2821. 
Farquhar, J., Johnston, D.T., Wing, B.A., 2007. Implications of conservation of mass effects on mass-dependent isotope fractionations: Influence of network structure on sulfur isotope phase space of dissimilatory sulfate reduction. Geochimica et Cosmochimica Acta 71, 58625875.

Farquhar, J., Johnston, D.T., Wing, B.A., Habicht, K.S., Canfield, D.E., Airieau, S.A., Thiemens, M.H., 2003. Multiple sulfur isotopic interpretations of biosynthetic pathways: Implications for biological signatures in the sulfur isotope record. Geobiology 1, 15-27. Forrest, J., Newman, L., 1977. Ag-110 microgram sulfate analysis for short time resolution of ambient levels of sulfur aerosol. Analytical Chemistry 49, 1579-1584.

Frigaard, N.-U., Bryant, D.A., 2008. Genomic insights into the sulfur metabolism of phototrophic green sulfur bacteria. Advances in Photosynthesis and Respiration, 337-355. Fry, B., Cox, J., Gest, H., Hayes, J.M., 1986. Discrimination between $S^{34}$ and $S^{32}$ during bacterial metabolism of inorganic sulfur-compounds. Journal of Bacteriology 165, 328-330. Fry, B., Gest, H., Hayes, J.M., 1985. Isotope effects associated with the anaerobic oxidation of sulfite and thiosulfate by the photosynthetic bacterium, Chromatium vinosum. FEMS Microbiology Letters 27, 227-232.

Fry, B., Jannasch, H.W., Molyneaux, S.J., Wirsen, C.O., Muramoto, J.A., King, S., 1991. Stable isotope studies of the carbon, nitrogen and sulfur cycles in the Black-Sea and the Cariaco Trench. Deep-Sea Research Part A-Oceanographic Research Papers 38, S1003S1019.

Fry, B., Ruf, W., Gest, H., Hayes, J.M., 1988. Sulfur isotope effects associated with oxidation of sulfide by $\mathrm{O}_{2}$ in aqueous solution. Chemical Geology 73, 205-210.

Galdenzi, S., Cocchioni, M., Morichetti, L., Amici, V., Scuri, S., 2008. Sulfidic groundwater chemistry in the Frasassi caves, Italy. Journal of Cave and Karst Studies 70, 94-107. 
Galdenzi, S., Maruoka, T., 2003. Gypsum deposits in the Frasassi caves, central Italy. Journal of Cave and Karst Studies 65, 111-125.

Ghosh, W., Dam, B., 2009. Biochemistry and molecular biology of lithotrophic sulfur oxidation by taxonomically and ecologically diverse bacteria and archaea. FEMS Microbiology Reviews 33, 999-1043.

Groger, J., Franke, J., Hamer, K., Schulz, H.D., 2009. Quantitative recovery of elemental sulfur and improved selectivity in a chromium-reducible sulfur distillation. Geostandards and Geoanalytical Research 33, 17-27.

Gomes, M.L., Hurtgen, M.T., 2015. Sulfur isotope fractionation in modern euxinic systems: Implications for paleoenvironmental reconstructions of paired sulfate-sulfide isotope records. Geochimica et Cosmochimica Acta 157, 39-55.

Habicht, K.S., Canfield, D.E., 2001. Isotope fractionation by sulfate-reducing natural populations and the isotopic composition of sulfide in marine sediments. Geology 29, 555558.

Habicht, K.S., Canfield, D.E., Rethmeier, J., 1998. Sulfur isotope fractionation during bacterial reduction and disproportionation of thiosulfate and sulfite. Geochimica et Cosmochimica Acta 62, 2585-2595.

Habicht, K.S., Gade, M., Thamdrup, B., Berg, P., Canfield, D.E., 2002. Calibration of sulfate levels in the Archean Ocean. Science 298, 2372-2374.

Hamilton, T., Jones, D.S., Schaperdoth, I., Macalady, J., 2014. Metagenomic insights into $\mathrm{S}(0)$ precipitation in a terrestrial subsurface lithoautotrophic ecosystem. Frontiers in Microbiology 5, 756.

Harrison, A.G., Thode, H.G., 1958. Mechanism of the bacterial reduction of sulphate from isotope fractionation studies. Transactions of the Faraday Society 54, 84-92. 
Hubert, C., Voordouw, G., Mayer, B., 2009. Elucidating microbial processes in nitrate- and sulfate-reducing systems using sulfur and oxygen isotope ratios: The example of oil reservoir souring control. Geochimica et Cosmochimica Acta 73, 3864-3879.

Huerta, P., Armenteros, I., Recio, C., Blanco, J.A., 2010. Palaeogroundwater evolution in playa-lake environments Sedimentary facies and stable isotope record (Palaeogene, Almazan basin, Spain). Palaeogeography Palaeoclimatology Palaeoecology 286, 135-148.

Hulston, J.R., Thode, H.G., 1965. Cosmic ray produced ${ }^{36} \mathrm{~S}$ and ${ }^{33} \mathrm{~S}$ in metallic phase of iron meteorites. Journal of Geophysical Research 70, 4435-4442.

Johnston, D.T., Farquhar, J., Canfield, D.E., 2007. Sulfur isotope insights into microbial sulfate reduction: When microbes meet models. Geochimica et Cosmochimica Acta 71, 3929-3947.

Johnston, D.T., Farquhar, J., Habicht, K., Canfield, D.E., 2008. Sulphur isotopes and the search for life: strategies for identifying sulphur metabolisms in the rock record and beyond. Geobiology 6, 425-435.

Johnston, D.T., Farquhar, J., Wing, B.A., Kaufman, A., Canfield, D.E., Habicht, K.S., 2005a. Multiple sulfur isotope fractionations in biological systems: A case study with sulfate reducers and sulfur disproportionators. American Journal of Science 305, 645-660. Johnston, D.T., Wing, B.A., Farquhar, J., Kaufman, A.J., Strauss, H., Lyons, T.W., Kah, L.C., Canfield, D.E., 2005b. Active microbial sulfur disproportionation in the Mesoproterozoic. Science 310, 1477-1479.

Jones, D.S., Polerecky, L., Galdenzi, S., Dempsey, B.A., Macalady, J.L., 2015. Fate of sulfide in the Frasassi Caves and implications for sulfuric acid speleogenesis. Chemical Geology 410, 21-27. 
Jones, D.S., Tobler, D.J., Schaperdoth, I., Mainiero, M., Macalady, J.L., 2010. Community Structure of Subsurface Biofilms in the Thermal Sulfidic Caves of Acquasanta Terme, Italy. Applied and Environmental Microbiology 76, 5902-5910.

Jones, D.S., Polerecky, L., Galdenzi, S., Dempsey, B.A. and Macalady, J.L., 2015. Fate of sulfide in the Frasassi cave system and implications for sulfuric acid speleogenesis. Chemical Geology 410, 21-27.

Jones, G.E., Starkey, R.L., 1957. Fractionation of stable isotopes of sulfur by microorganisms and their role in deposition of native sulfur. Applied Microbiology 5, 111-118.

Jorgensen, B.B., 1982. Mineralization of organic matter in the sea bed - the role of sulphate reduction. Nature 296, 643-645.

Jorgensen, B.B., 1990. A thiosulfate shunt in the sulfur cycle of marine sediments. Science $249,152-154$.

Kamyshny, A., Zerkle, A.L., Mansaray, Z.F., Ciglenecki, I., Bura-Nakic, E., Farquhar, J., Ferdelman, T.G., 2011. Biogeochemical sulfur cycling in the water column of a shallow stratified sea-water lake: Speciation and quadruple sulfur isotope composition. Marine Chemistry 127, 144-154.

Kaplan, I.R., Emery, K.O., Rittenberg, S.C., 1963. The distribution and isotopic abundance of sulphur in recent marine sediments off southern California Geochimica et Cosmochimica Acta 27, 297-319.

Kaplan, I.R., Rafter, T.A., 1958. Fractionation of stable isotopes of sulfur by Thiobacilli. Science 127, 517-518.

Kaplan, I.R., Rittenberg, S.C., 1962. Fractionation of isotopes in relation to problem of elemental sulphur transport by micro-organisms. Nature 194, 1098-\&.

Kaplan, I.R., Rittenberg, S.C., 1964. Microbiological fractionation of sulphur isotopes. Journal of General Microbiology 34, 195-\&. 
Kelly, D.P., 2008. Stable sulfur isotope fractionation and discrimination between the sulfur atoms of thiosulfate during oxidation by Halothiobacillus neapolitanus. Fems Microbiology Letters 282, 299-306.

Lepland, A., Joosu, L., Kirismae, K., Prave, A.R., Romashkin, A.E., Crne, A.E., Martin, A.P., Fallick, A.E., Somelar, P., Upraus, K., Mand, K., Roberts, N.M.W., van Zuilen, M.A., Wirth, R., Schreiber, A., 2014. Potential influence of sulphur bacteria on Palaeoproterozoic phosphogenesis. Nature Geoscience 7, 20-24.

Li, X., Gilhooly, W.P., III, Zerkle, A.L., Lyons, T.W., Farquhar, J., Werne, J.P., Varela, R., Scranton, M.I., 2010. Stable sulfur isotopes in the water column of the Cariaco Basin.

Geochimica et Cosmochimica Acta 74, 6764-6778.

Macalady, J.L., Dattagupta, S., Schaperdoth, I., Jones, D.S., Druschel, G.K., Eastman, D., 2008. Niche differentiation among sulfur-oxidizing bacterial populations in cave waters. the ISME Journal, 1-12.

Macalady, J.L., Lyon, E.H., Koffman, B., Albertson, L.K., Meyer, K., Galdenzi, S., Mariani, S., 2006. Dominant microbial Populations in limestone-corroding stream biofilms, Frasassi cave system, Italy. Applied and Environmental Microbiology 72, 5596-5609.

Mariani, S., Mainiero, M., Barchi, M., van der Borg, K., Vonhof, H., Montanari, A., 2007. Use of speleologic data to evaluate Holocene uplifting and tilting: An example from the Frasassi anticline (northeastern Apennines, Italy). Earth and Planetary Science Letters 257, 313-328.

McCready, R.G.L., Krouse, H.R., 1982. Sulfur isotope fractionation during the oxidation of elemental sulfur by Thiobacilli in a solonetzic soil. Canadian Journal of Soil Science 62, 105 110.

Nelson, D.C., Castenholz, R.W., 1981. Use of reduced sulfur compounds by Beggiatoa sp. Journal of Bacteriology 147, 140-154. 
Neretin, L.N., Bottcher, M.E., Grinenko, V.A., 2003. Sulfur isotope geochemistry of the Black Sea water column. Chemical Geology 200, 59-69.

Pellerin, A., Bui, T.H., Rough, M., Mucci, A., Canfield, D.E., Wing, B.A., 2015. Massdependent sulfur isotope fractionation during reoxidative sulfur cycling: A case study for Mangrove Lake, Bermuda. Geochimica et Cosmochimica Acta 149, 152-164.

Poser, A., Vogt, C., Knoller, K., Ahlheim, J., Weiss, H., Kleinsteuber, S., Richnow, H.H., 2014. Stable sulfur and oxygen isotope fractionation of anoxic sulfide oxidation by two different enzymatic pathways. Environmental Science \& Technology.

Sauve, V., Bruno, S., Berks, B.C., Hemmings, A.M., 2007. The SoxYZ complex carries sulfur cycle intermediates on a peptide swing arm. The Journal of Biological Chemistry 282, 23194-23204.

Schidlowski, M., Hayes, J.M., Kaplan, I.R., 1983. Isotopic inferences of ancient biochemistries: Carbon, sulfur, hydrogen, and nitrogen, in: Schopf, J.W. (Ed.), The Earth's Earliest Biosphere. Princeton University Press, Princeton, pp. 149-185.

Schmidt, T.M., Arieli, B., Cohen, Y., Padan, E., Strohl, W.R., 1987. Sulfur metabolism in Beggiatoa alba. Journal of Bacteriology 169, 5466-5472.

Sim, M.S., Bosak, T., Ono, S., 2011a. Large Sulfur Isotope Fractionation Does Not Require Disproportionation. Science 333, 74-77.

Sim, M.S., Ono, S., Donovan, K., Templer, S.P., Bosak, T., 2011b. Effect of electron donors on the fractionation of sulfur isotopes by a marine Desulfovibrio sp. Geochimica Et Cosmochimica Acta 75, 4244-4259.

Troelsen, H., Jorgensen, B.B., 1982. Seasonal dynamics of elemental sulfur in 2 coastal sediments. Estuarine Coastal and Shelf Science 15, 255-266. 
Wing, B.A., Halevy, I., 2014. Intracellular metabolite levels shape sulfur isotope fractionation during microbial sulfate respiration. Proceedings of the National Academy of Sciences 111, 18116-18125.

Wortmann, U.G., Bernasconi, S.M., Bottcher, M.E., 2001. Hypersulfidic deep biosphere indicates extreme sulfur isotope fractionation during single-step microbial sulfate reduction. Geology 29, 647-650.

Wu, N., Farquhar, J., Strauss, H., Kim, S.-T., Canfield, D.E., 2010. Evaluating the S-isotope fractionation associated with Phanerozoic pyrite burial. Geochimica et Cosmochimica Acta 74, 2053-2071.

Zerkle, A.L., Farquhar, J., Johnston, D.T., Cox, R.P., Canfield, D.E., 2009. Fractionation of multiple sulfur isotopes during phototrophic oxidation of sulfide and elemental sulfur by a green sulfur bacterium. Geochimica et Cosmochimica Acta 73, 291-306.

Zerkle, A.L., Kamyshny, A., Kump, L.R., Farquhar, J., Oduro, H., Arthur, M.A., 2010. Sulfur cycling in a stratified euxinic lake with moderately high sulfate: Constraints from quadruple S isotopes. Geochimica et Cosmochimica Acta 74, 4953-4970. 
Table 1. Sulfur isotope fractionations measured in previous laboratory experiments with chemotrophic $\mathrm{S}$-oxidizing organisms and abiotic oxidation processes

\begin{tabular}{|c|c|c|c|c|}
\hline Reactant & Product(s) & Organism(s) & ${ }^{34} \varepsilon(\%)$ & Reference \\
\hline \multirow[t]{4}{*}{$\mathrm{H}_{2} \mathrm{~S}$} & $S^{0}$ & Thiobacillus (T.) thiooxidans $^{a}$ & -2.5 to +1.2 & 1 \\
\hline & $\mathrm{S}_{\mathrm{x}} \mathrm{O}_{6}^{2-\mathrm{b}}$ & T. thiooxidans ${ }^{a}$ & +0.6 to +19 & 1 \\
\hline & $\mathrm{SO}_{4}^{2-\mathrm{b}}$ & T. thiooxidans ${ }^{a}$ & -18 to -10.5 & 1 \\
\hline & $\mathrm{S}^{0}, \mathrm{~S}_{2} \mathrm{O}_{3}{ }^{2-}, \mathrm{SO}_{4}{ }^{2-}$ & $\mathrm{O}_{2}$, abiotic & -4 to -5 & 2 \\
\hline \multirow[t]{3}{*}{$\mathrm{H}_{2} \mathrm{~S}$ (with $\mathrm{NO}_{3}{ }^{2-}$ ) } & $S^{0}(?)^{c}$ & Thiomicrospira sp. & 0 & 3 \\
\hline & $\mathrm{SO}_{4}{ }^{2-}$ & Thiobacillus denitrificans & -4.3 to -1.3 & 4 \\
\hline & $\mathrm{SO}_{4}^{2-}$ & Sulfurionas denitrificans & -2.9 to -1.6 & 4 \\
\hline \multirow[t]{4}{*}{$S^{0}$} & $\mathrm{SO}_{4}{ }^{2-}$ & T. thiooxidans ${ }^{a}$ & -0.1 to +1.4 & 5,6 \\
\hline & $\mathrm{SO}_{4}{ }^{2-}$ & T. thiooxidans & -1.7 to 0 & 7,8 \\
\hline & $\mathrm{SO}_{4}{ }^{2-}$ & T. thioparus & -1.2 & 8 \\
\hline & $\mathrm{SO}_{4}{ }^{2-}$ & Acidithiobacillus ferrooxidans & -0.9 to -2.2 & 9 \\
\hline $\mathrm{S}^{0}(\text { ? })^{\mathrm{C}}\left(\right.$ with $\left.\mathrm{NO}_{3}{ }^{2-}\right)$ & $\mathrm{SO}_{4}{ }^{2-}$ & Thiomicrospira sp. & -2 & 3 \\
\hline \multirow[t]{5}{*}{$\mathrm{S}_{2} \mathrm{O}_{3}{ }^{2-}$} & $\mathrm{SO}_{4}^{2-}$ & Paracoccus versutus $^{d}$ & 0.4 & 10 \\
\hline & $\mathrm{SO}_{4}{ }^{2-}$ & Halothiobacillus neapolitanus & +1.2 to +2.9 & 11 \\
\hline & $\mathrm{SO}_{4}{ }^{2-}$ & Paracoccus pantothrophus & -5.8 to +1.8 & 12 \\
\hline & $\mathrm{SO}_{4}{ }^{2-}$ & Tetrathiobacter kashmirensis & -4.9 to -0.8 & 12 \\
\hline & $\mathrm{SO}_{4}{ }^{2-}$ & Thiomicrospira crunogena & -1.9 to +4.6 & 12 \\
\hline $\mathrm{SO}_{3}{ }^{2-}$ & $\mathrm{SO}_{4}{ }^{2-}$ & $\mathrm{O}_{2}$, abiotic & +0.4 & 13 \\
\hline
\end{tabular}

1. Kaplan and Rittenberg, 1964; 2. Fry et al., 1988; 3. Hubert et al., 2009; 4. Poser et al., 2014; 5. Kaplan and Rafter, 1958; 6. Kaplan and Rittenberg, 1962; 7. Jones and Starkey, 1957; 8. McCready and Krouse, 1982; 9. Balci et al., 2012; 10. Fry et al., 1986; 11. Kelly, 2008; 12. Alam et al., 2013; 13. Fry et al., 1985

a originally classified as $T$. concretivorus

${ }^{\mathrm{b}}$ minor reaction products formed along with $\mathrm{S}^{0}$ or $\mathrm{SO}_{4}{ }^{2-}$

${ }^{c}$ unquantified intermediate assumed to be $\mathrm{S}^{0}$

doriginally classified as $T$. versutus 
Table 2. Sites sampled and geochemical parameters measured.

\begin{tabular}{|c|c|c|c|c|c|c|c|c|c|}
\hline Year/Site & Site & $\begin{array}{c}\text { sample } \\
\#\end{array}$ & $\mathrm{~T}^{\circ} \mathrm{C}$ & $\mathrm{pH}$ & $\begin{array}{l}\text { Sp Cond } \\
(\mathrm{mS} / \mathrm{cm})\end{array}$ & $\begin{array}{c}\mathrm{O}_{2} \\
(\mathrm{mg} / \mathrm{L})\end{array}$ & $\begin{array}{c}\mathrm{H}_{2} \mathrm{~S}(\mathrm{aq}) \\
(\mathrm{mg} / \mathrm{L})\end{array}$ & $\begin{array}{c}\mathrm{SO}_{4}(\mathrm{aq}) \\
(\mathrm{mg} / \mathrm{L})\end{array}$ & $\begin{array}{l}\mathrm{H}_{2} \mathrm{~S} / \mathrm{O}_{2} \\
\text { (molar) }\end{array}$ \\
\hline \multicolumn{10}{|l|}{2009} \\
\hline Pozzo di Cristali (PC) & cave stream & $1-5$ & 13.5 & 7.2 & 3.1 & $0.1-1.4$ & $15-18$ & $155-183$ & $11-600$ \\
\hline Ramo Sulfureo (RS) & cave pond & $1-3$ & 13.6 & 7.2 & 2.1 & 0.1 & 10 & $25-48$ & 83 \\
\hline \multicolumn{10}{|l|}{2010} \\
\hline Pozzo di Cristali & cave stream & 6 & 13.6 & 7.3 & 2.9 & 0.03 & 15 & 110 & 510 \\
\hline Grotta Sulfurea (GS) & cave stream & 1 & 13.3 & 7.4 & 1.5 & 0.9 & 1 & 90 & 1 \\
\hline Cave Springs (CS) & outflow & 1 & 13.3 & 7.4 & 1.6 & 1.9 & 1 & 114 & 1 \\
\hline Vecchio (VC) & outflow & 1 & 13.3 & 7.3 & 1.6 & 1.1 & 1 & 200 & 1 \\
\hline \multicolumn{10}{|l|}{2011} \\
\hline Pozzo di Cristali & cave stream & $7-13$ & 13.7 & 7.3 & 2.8 & $0.4-2.1$ & $4-10$ & & $4-18$ \\
\hline Grotta Sulfurea & cave stream & $2-4$ & 13.9 & 7.4 & 2.1 & $1.3-1.5$ & $2-4$ & & $2-3$ \\
\hline Cave Springs & outflow & $2-5$ & 14.0 & 7.3 & 2.1 & $0.8-1.7$ & $4-5$ & & $2-7$ \\
\hline Fissure Springs (FS) & outflow & $1-2$ & 17.5 & 7.3 & 2.2 & 3.2 & $10-12$ & & $3-4$ \\
\hline Lago Verde (LV) & cave lake & $1-4$ & 14.0 & 7.3 & 2.9 & 0.1 & $7-10$ & & $97-136$ \\
\hline
\end{tabular}


Table 3. $\mathrm{S}$ isotope values measured for aqueous sulfide and sulfate, and for AVS and CRS extracted from sediments. Also shown are fractionations for ${ }^{34} S\left({ }^{34} \varepsilon\right)$ and exponents relating ${ }^{33} S$ and ${ }^{34} S\left({ }^{33} \lambda\right.$, with error $\left.\mathrm{s}_{\lambda}\right)$ calculated between the relevant species (as explained in the text).

\begin{tabular}{|c|c|c|c|c|c|c|c|c|c|c|c|c|c|c|c|c|c|}
\hline Sample & $\delta^{34} S$ & $\Delta^{33} S$ & $\delta^{34} S$ & $\Delta^{33} S$ & $\delta^{34} S$ & $\Delta^{33} S$ & $\delta^{34} S$ & $\Delta^{33} S$ & ${ }^{34} \varepsilon$ & ${ }^{33} \lambda$ & $\sigma_{\lambda}$ & ${ }^{34} \varepsilon$ & ${ }^{33} \lambda$ & $\sigma_{\lambda}$ & ${ }^{34} \varepsilon$ & ${ }^{33} \lambda$ & $\sigma_{\lambda}$ \\
\hline & \multicolumn{2}{|c|}{ sulfide (aq) } & \multicolumn{2}{|c|}{ sulfate (aq) } & \multicolumn{2}{|c|}{ AVS sediments } & \multicolumn{2}{|c|}{ CRS sediments } & \multicolumn{3}{|c|}{ sulfide-sulfate } & \multicolumn{3}{|c|}{ AVS-sulfate } & \multicolumn{3}{|c|}{ CRS-sulfate } \\
\hline PC-1 & -13.17 & 0.062 & 21.59 & 0.040 & & & & & -34.02 & 0.5143 & 0.005 & & & & & & \\
\hline PC-2 & -14.54 & 0.085 & 21.28 & 0.054 & & & & & -35.07 & 0.5141 & 0.004 & & & & & & \\
\hline PC-3 & -14.71 & 0.086 & 21.63 & 0.049 & & & & & -35.57 & 0.5139 & 0.004 & & & & & & \\
\hline PC-4 & & & 22.10 & 0.049 & & & & & & & & & & & & & \\
\hline PC-5 & -14.75 & 0.075 & 19.13 & 0.046 & & & & & -33.24 & 0.5141 & 0.005 & & & & & & \\
\hline PC-6 & -15.44 & 0.061 & 22.50 & 0.034 & & & & & -37.11 & 0.5143 & 0.004 & & & & & & \\
\hline PC-7 & -15.59 & 0.078 & 14.62 & 0.062 & -20.25 & 0.094 & -20.00 & 0.057 & -29.78 & 0.5144 & 0.006 & -34.36 & 0.5140 & 0.005 & -34.12 & 0.5151 & 0.002 \\
\hline PC-8 & -15.77 & 0.085 & 19.46 & & -17.20 & 0.044 & -15.41 & 0.096 & -34.56 & & & -35.96 & & & -34.21 & & \\
\hline PC-9 & -15.60 & 0.078 & 20.27 & 0.060 & -21.43 & 0.093 & -19.79 & 0.110 & -35.16 & 0.5145 & 0.004 & -40.87 & 0.5142 & 0.003 & -39.27 & 0.5137 & 0.002 \\
\hline PC-10 & -15.38 & 0.080 & 20.08 & & -19.72 & 0.118 & -22.78 & 0.120 & -34.77 & & & -39.02 & & & -42.02 & & \\
\hline PC-11 & -15.79 & 0.080 & 19.11 & & -18.09 & & -17.17 & & -34.25 & & & -36.50 & & & -35.60 & & \\
\hline PC-12 & -15.37 & 0.083 & 20.42 & 0.042 & -17.08 & & -17.22 & 0.083 & -35.07 & 0.5138 & 0.004 & -36.75 & & & -36.89 & 0.5139 & 0.002 \\
\hline$P C-13$ & -16.73 & 0.084 & 19.43 & & -19.29 & 0.066 & -18.85 & 0.081 & -35.47 & & & -37.98 & & & -37.55 & & \\
\hline RS-1 & -16.69 & 0.083 & 21.52 & 0.023 & & & & & -37.40 & 0.5134 & 0.004 & & & & & & \\
\hline RS-2 & -17.28 & 0.065 & 20.18 & 0.050 & & & & & -36.72 & 0.5146 & 0.004 & & & & & & \\
\hline RS-3 & -14.54 & 0.085 & 19.01 & 0.036 & & & & & -32.92 & 0.5135 & 0.005 & & & & & & \\
\hline GS-1 & -19.61 & 0.054 & 16.48 & 0.027 & & & & & -35.51 & 0.5142 & 0.004 & & & & & & \\
\hline GS-2 & -19.99 & 0.069 & 19.43 & 0.043 & -20.46 & & -23.28 & 0.049 & -38.66 & 0.5143 & 0.004 & -39.13 & & & -41.89 & 0.5148 & 0.002 \\
\hline GS-3 & & & 18.71 & & & & & & & & & & & & & & \\
\hline GS-4 & -19.92 & 0.071 & 18.78 & 0.037 & -20.82 & & -23.27 & & -37.99 & 0.5141 & 0.004 & -38.88 & & & -41.28 & & \\
\hline CS-1 & -18.99 & 0.072 & 16.36 & 0.018 & & & & & -34.79 & 0.5134 & 0.004 & & & & & & \\
\hline CS-2 & -17.69 & 0.075 & 19.52 & 0.039 & & & -16.27 & 0.098 & -36.49 & 0.5140 & 0.004 & & & & -35.10 & 0.5133 & 0.002 \\
\hline CS-3 & -17.79 & 0.076 & 19.74 & & & & -16.67 & & -36.80 & & & & & & -35.70 & & \\
\hline CS-4 & -17.81 & 0.081 & 20.04 & & & & & & -37.10 & & & & & & & & \\
\hline CS-5 & -18.01 & 0.095 & 19.25 & 0.012 & -20.01 & 0.094 & -16.80 & 0.089 & -36.56 & 0.5127 & 0.004 & -38.53 & 0.5129 & 0.004 & -35.37 & 0.5128 & 0.002 \\
\hline
\end{tabular}




\begin{tabular}{|c|c|c|c|c|c|c|c|c|c|c|c|c|c|c|c|c|c|}
\hline VC-1 & -21.16 & 0.062 & 18.09 & 0.025 & & & & & -38.55 & 0.5140 & 0.004 & & & & & & \\
\hline FS-1 & -14.22 & 0.094 & 21.16 & & -15.70 & 0.092 & -19.21 & 0.093 & -34.64 & & & -36.09 & & & -39.53 & & \\
\hline FS-2 & -13.91 & 0.083 & 22.16 & 0.082 & -15.35 & & -17.97 & & -35.28 & 0.5149 & 0.004 & -37.97 & & & & & \\
\hline LV-1 & -15.06 & 0.079 & 21.77 & 0.070 & -17.03 & 0.098 & -24.02 & 0.122 & -36.04 & 0.5147 & 0.004 & -35.79 & 0.5142 & 0.004 & -44.81 & 0.5138 & 0.001 \\
\hline LV-2 & -15.13 & 0.077 & 20.01 & 0.049 & -16.49 & & -20.21 & & -34.45 & 0.5142 & 0.005 & & & & -39.43 & & \\
\hline LV-3 & -15.26 & 0.081 & 19.54 & & & & & & -34.13 & & & & & & & & \\
\hline LV-4 & -15.27 & 0.083 & 21.10 & & & & & & -35.62 & & & & & & & & \\
\hline
\end{tabular}


Table 4. $\mathrm{S}$ isotope values measured for elemental sulfur extracted from biofilms, along with fractionations calculated between $S^{0}$ and aqueous sulfide from adjacent samples.

\begin{tabular}{|c|c|c|c|c|}
\hline Sample & $\delta^{34} S$ & $\Delta^{33} S$ & ${ }^{34} \varepsilon$ & ${ }^{33} \mathrm{E}$ \\
\hline & \multicolumn{2}{|c|}{$S^{0}$, streamers } & \multicolumn{2}{|c|}{$S^{0}$-sulfide } \\
\hline PC-3 & -13.27 & 0.096 & 1.47 & 0.010 \\
\hline PC-3 & -14.95 & 0.080 & -0.24 & -0.006 \\
\hline PC-9 & -13.76 & 0.117 & 1.87 & 0.039 \\
\hline PC-10 & -12.14 & 0.087 & 3.30 & 0.006 \\
\hline PC-12 & -15.64 & 0.080 & -0.28 & -0.003 \\
\hline RS-1 & -13.81 & 0.090 & 2.92 & 0.007 \\
\hline RS-2 & -13.76 & 0.083 & 3.58 & 0.018 \\
\hline RS-3 & -13.79 & 0.079 & 0.76 & -0.006 \\
\hline GS-1 & -14.91 & 0.073 & 4.80 & 0.018 \\
\hline CS-1 & -15.58 & 0.067 & 3.48 & -0.005 \\
\hline CS-2 & -15.58 & 0.105 & 2.14 & 0.030 \\
\hline CS-3 & -15.16 & 0.121 & 2.69 & 0.045 \\
\hline CS-4 & -10.00 & 0.026 & 7.95 & -0.056 \\
\hline CS-5 & -18.24 & 0.096 & -0.24 & 0.001 \\
\hline CS-5 & -9.73 & 0.050 & 8.43 & -0.046 \\
\hline \multirow[t]{2}{*}{ VC-1 } & -15.59 & 0.063 & 5.69 & 0.001 \\
\hline & \multicolumn{2}{|c|}{$s^{0}, s W I B S$} & \multicolumn{2}{|c|}{$S^{0}$-sulfide } \\
\hline PC-1 & -12.17 & 0.077 & 1.01 & 0.015 \\
\hline PC-1 & -12.38 & 0.085 & 0.79 & 0.023 \\
\hline PC-7 & -13.90 & 0.066 & 1.72 & -0.012 \\
\hline PC-8 & -14.56 & & 1.24 & \\
\hline PC-9 & -14.52 & 0.088 & 1.09 & 0.010 \\
\hline PC-10 & -16.17 & 0.092 & -0.80 & 0.012 \\
\hline PC-11 & -14.73 & & 1.08 & \\
\hline PC-12 & -13.43 & 0.046 & 1.97 & -0.037 \\
\hline PC-13 & -13.60 & 0.094 & 3.18 & 0.010 \\
\hline GS-1 & -14.65 & 0.069 & 5.06 & 0.014 \\
\hline GS-1 & -14.91 & 0.073 & 4.80 & 0.018 \\
\hline GS-2 & -14.84 & 0.048 & 5.25 & -0.021 \\
\hline GS-3 & -15.79 & 0.073 & 4.28 & 0.004 \\
\hline GS-4 & -17.51 & 0.098 & 2.46 & 0.027 \\
\hline CS-2 & -16.47 & 0.065 & 1.24 & -0.010 \\
\hline CS-3 & -15.91 & & 1.91 & \\
\hline CS-5 & -16.15 & 0.052 & 1.89 & -0.044 \\
\hline CS-5 & -13.21 & & 4.89 & \\
\hline FS-1 & -15.10 & 0.071 & -0.90 & -0.023 \\
\hline LV-1 & -14.77 & 0.084 & 0.30 & 0.006 \\
\hline LV-2 & -16.87 & & 1.77 & \\
\hline
\end{tabular}

